\title{
Doenças Infecciosas Emergentes no Reino da Complexidade: Implicações Para as Políticas Científicas e Tecnológicas
}

\section{Emerging Infectious Diseases in the Realm of Complexity: Implications for Scientific and Technological Policies}

\section{Marília B. Marques ${ }^{1}$}

\section{MARQUES, M. B. Emerging Infectious Diseases in the Realm of Complexity: Implications} for Scientific and Technological Policies. Cad. Saúde Públ., Rio de Janeiro, II (3): 361-388, Jul/Sep, 1995.

The current emergence and global dissemination of some new and resurgent infectious diseases have surpassed national frontiers, increasingly affecting developing and also developed countries. This study stresses that this outburst is affecting the predictability of dominant health transition approaches. This paper analyses, from epistemological and policy viewpoints, alternative approaches in order to confront these new global epidemiological trends.

Key words: Virus; Human Parasites; Infectious Diseases; Epidemiological Transition; Complexity

\section{INTRODUÇÃO}

Surpreendentemente, as doenças infecciosas emergentes e re-emergentes, voltaram a colocar os sistemas de saúde de países desenvolvidos e em desenvolvimento frente a frente com uma série de incertezas e riscos de grande magnitude.

Sucessivamente, vão sendo descritos novos episódios de infecções, como a pandemia global do HIV/AIDS, a contínua disseminação dos vírus da dengue e o freqüente aparecimento de doenças previamente não reconhecidas como as febres hemorrágicas, além do ressurgimento da tuberculose e da cólera, em novas formas.

Doenças infecciosas emergentes estão estimulando discussões de temas políticos, como as possíveis conexões entre engenharia genética/novos agentes patógenos e armas biológicas (Geissler, 1993; FAS, 1993), o tráfico global de viroses (Morse, 1993), o intercâmbio de doenças entre o velho e o novo

\footnotetext{
${ }^{I}$ Núcleo de Estudos em Ciência e Tecnologia, Centro de Informações Científicas e Tecnológicas em Saúde, Fundação) Oswaldo Cruz. Av. Brasil, 4036, 7aaa, Rio de Janeiro, RJ, 21040-361, Brasil.
}

mundo (Berlinguer, 1993). Além do mais, estão renovando as esperanças de que a cooperação científica etecnológica internacional ajude a decifrá-las e impeça a propagação mundial (Jain, 1991; Doll, 1992). A Federation of American Scientists (FAS), por exemplo, defende um Programa para o Monitoramento de Doenças Emergentes (ProMED), de alcance global (FAS, 1993).

Simultaneamente, grandes mudanças estão se processando no, interior da pesquisa em saúde, sobretudo no campo da biologia molecular e do desenvolvimento das técnicas de engenharia genética e as perspectivas científicas e tecnológicas para a intervenção sobre as doenças infecciosas e parasitárias nunca foram tão promissoras.

A tomada de decisões políticas e gerenciais, internacionalmente, depara-se, portanto, com os novos desafios de esclarecer e explicitar os riscos e as oportunidades na definição da agenda de pesquisa em saúde e na escolha de tecnologias estratégicas.

Neste trabalho discutimos uma possível estratégia alternativa para enfocar tais fenômenos complexos, concentrando-nos, sobretudo, nas implicações que o tema oferece para a formulação de políticas científicas e tecnológicas em saúde. 


\section{O PROBLEMA}

Em 1993, nos Estados Unidos, as investigações epidemiológicas de casos de doença grave, devido à Escherichia coli cepa O157:H7, comprovaram a relação com o consumo de carne moída industrializada, servida em cadeia de restaurantes de fastfood (Berkelman et al., 1994).

Surtos de doenças como essa, desconhecidas ou não, de origem infecciosa, que passam a ter uma incidência crescente em seres humanos, em um período de tempo recente e que apresentam riscos de aumento progressivo no futuro próximo, introduzem o conceito de doenças emergentes e re-emergentes, também denominadas de novas doenças infecciosas.

Em geral, são infecções não reconhecidas previamente e que acometem pessoas vivendo ou trabalhando em áreas que atravessam mudanças ecológicas: o deflorestamento e o reflorestamento aumentam a exposição a insetos, animais e a fontes ambientais que podem albergar agentes infecciosos novos ou incomuns.

Estudos da distribuição geográfica de parasitas e de doenças transmitidas por vetores revelam a existência de sinergismos entre destruição de florestas tropicais, perda de biodiversidade e alterações climáticas, com impactos potenciais em saúde (Dobson \& Carper, 1993; Skole \& Tucker, 1993; Walsh et al., 1993). Somam-se novas doenças em seres humanos e novas ocorrências em plantas e animais, atestando a contínua vulnerabilidade global às doenças infecciosas.

A emergência da doença de Lyme, desconhecida nos Estados Unidos até duas décadas atrás, foi, em parte, conseqüência do reflorestamento e do crescimento de populações de veados, no nordeste americano. Atualmente, é a doença transmitida por artrópodes mais comum naquele país, causa de elevada morbidade em áreas suburbanas e rurais (Barbour \& Fish, 1993).

No Brasil, além do recrudescimento da malária em áreas de garimpo, da dengue, do HIV/ AIDS, da cólera, são descritas entre as doenças emergentes algumas viroses como a febre oropouche e a encefalite do rocio (FAS, 1993). Recentemente, foi isolado um novo arenavirus, denominado Sabiá, a partir de um caso fatal de febre hemorrágica, inicialmente diagnosticado como sendo febre amarela (Coimbra et al., 1994).

O Centers for Diseases Control and Prevention (CDC, 1994) considera que as novas doenças infecciosas, tanto podem ser o resultado de mudanças evolutivas nos microorganismos, como podem resultar da disseminação de doenças conhecidas para novas áreas geográficas ou novas populações humanas.

Além das anteriormente mencionadas, o CDC fornece outros exemplos de doenças infecciosas emergentes e re-emergentes verificadas nos Estados Unidos: Cryptosporidiosis; Coccidioidomycosis; doença pneumocóccica resistente a múltiplas drogas; infeccções enterocóccicas resistentes à vancomicina; Influenza A/Beijing/ 32/92; infecções por Hantavirus.

Fora dos Estados Unidos, o CDC fornece os seguintes exemplos: Cólera, na América Latina; Febre Amarela, no Kenya; Vibrio cholerae O139, na Ásia; E. coli O157:H7, na África do Sul e em Swaziland; Febre do Rift Valley, no Egito; Shigella dysenteriae resistente a múltiplas drogas, em Burundi; Dengue na Costa Rica; Difteria, na Rússia.

A re-emergência de doenças infecciosas também é associada ao desenvolvimento de resistência aos agentes terapêuticos conhecidos (por exemplo: malária, doença pneumocóccica) e à interrupção de medidas previamente disponíveis para o controle de infecções como cólera, tuberculose, coqueluche.

Nos últimos 20 anos, também as infecções por fungos oportunistas aumentaram acentuadamente e hoje muito contribuem para a morbomortalidade em ambientes hospitalares. São freqüentes os casos de candidíase invasiva, de aspergilose pulmonar invasiva, de pneumonia por Pneumocystis carinii. Este crescimento, em parte, foi um resultado paradoxal dos avanços médicos, incidindo, sobretudo, em indivíduos tratados com agentes antibacterianos de largo espectro, ou submetidos a procedimentos invasivos, como catéteres e dispositivos protéticos e na supressão imunológica verificada em pacientes transplantados, na quimioterapia do câncer, nos casos de HIV/AIDS, entre outras condições debilitantes (Georgopapadakou $\&$ Walsh, 1994). 
O Institute of Medicine (IOM, 1992) lançou, nos Estados Unidos, em 1992, um relatório entitulado "Emerging Infections: Microbial Threats to Health in the United States", reafirmando que as novas doenças desconhecem fronteiras nacionais e reconhecendo que o sistema de saúde dos Estados Unidos não está capacitado para detectar surtos de novas doenças infecciosas.

O CDC (1994) propôs a criação de um sistema para fortalecimento da vigilância global das infecções emergentes enfatizando, entre outros aspectos, o fortalecimento das notificações, o estabelecimento de redes sentinelas de vigilância e de centros de pesquisa epidemiológica.

A situação atual nos sugere, portanto, que múltiplos e complexos fatores parecem contribuir com a presente explosão das novas doenças infecciosas, as quais, por sua vez, estão dando novo impulso à pesquisa em saúde.

Tendo em conta as inúmeras incertezas que cercam estas doenças, para levar adiante nossas discussões, partiremos da seguinte indagação geral: Serão as doenças infecciosas emergentes e re-emergentes resultados negativos da ação do homem sobre sistemas naturais que tem levado à degradação dos sistemas ecológicos planetários?

\section{O TEMPO E SUAS RACIONALIDADES}

Afirmar que ciência, tecnologia, sociedade e dinâmica evolutiva formam um conjunto de noções complexas é fazer uma assertiva óbvia. Não constitui, porém, uma obviedade, afirmar que o tempo exerce um papel importante na definição dessa complexidade. Tempo e risco também constituem dois importantes elementos na análise do processo de desenvolvimento científico e tecnológico.

Concordando com Bifani (1993), pensamos que o tempo deve ser considerado segundo diferentes racionalidades. A racionalidade do tempo social é fundamentalmente de curto prazo; a do tempo do desenvolvimento científico e tecnológico é, basicamente, de longo prazo; a racionalidade do tempo da dinâmica evolutiva dos sistemas naturais é, essencialmente, de muito longo prazo.

Alguns autores consideram, com criticismo, que os métodos e técnicas contemplados pelas análises formais do risco em saúde têm um corte predominantemente utilitarista, lógico-positivista, no qual a predição de eventos visa à diminuição da sua ocorrência pela redução da margem de incerteza (Hayes, 1992).

De fato, é a previsibilidade do risco de ocorrência de eventos que possibilita orientar a intervenção, permitindo que a racionalidade de curto prazo predomine no tempo social em saúde. As críticas não deveriam esquecer as motivações práticas presentes no horizonte das análises de risco em saúde: além do controle e erradicação de doenças, incluem a avaliação de produtos e procedimentos médicos, a avaliação de desastres tecnológicos e naturais e os planos de seguro saúde.

Diferentemente, entretanto, na lógica de muito longo prazo dominante na dinâmica evolutiva dos sistemas naturais, a imprevisibilidade introduz complexidade. Como orientar a intervenção quando se está diante de fatos imprevisíveis?

A evolução é um processo baseado na transmissão de informação. Os intervalos de tempo nos processos evolucionários são longos, podendo ser centenários, seculares. A prosperidade humana teria no desenvolvimento do cérebro, no plano biológico, a sua mais significativa característica evolucionária pregressa. $\mathrm{O}$ desenvolvimento da espécie humana é, em sua maior parte, tributado à evolução cultural, não se tratando de mera evolução genética. Na espécie humana, a evolução cultural possibilita que a experiência adquirida possa ser transmitida oralmente ou através da palavra escrita de uma geração para a seguinte.

Com o advento do paradigma da informação, das técnicas de computação (Marques, 1991; Gallopín, 1992), a capacidade de acumular e transmitir informações ampliou-se de tal modo que provocou uma aceleração no tempo evolucionário do homem. O processo evolucionário (de comunicação/troca de informação) humano consome muito menos tempo em comparação com o das outras espécies biológicas.

Conseqüências negativas desse sucesso evolutivo do homem seriam as muitas mudanças, qualitativas e quantitativas, verificadas nos componentes incerteza e risco no cotidiano da vida. Os problemas ecológicos e ambientais da atua- 
lidade costumam ser vistos como sendo conseqüências, em essência. do sucesso biológico da espécie humana e do papel dominante da ação do homem sobre os diversos ecossistemas e de sua capacidade de dominar mecanismos de controle biológico (Holliday, 1983: Smith. 1986). A acumulação de informação científica nas ciências da vida. ao mesmo tempo que possibilitou ao homem manipular a informação genética. também implicou a diminuição da biodiversidade global. através da intervenção humana nos ecossistemas naturais. Mudanças dramáticas na sociedade, na tecnolooia e no ambiente estariam, portanto, conduzindo a humanidade para uma nova era de confronto com a morte e com a invalidez. Estariam favorecendo a evolução/disseminação de agentes patogênicos, fazendo com que o espectro de doenças infecciosas se altere e expanda.

As reflexões de Tiezzi (1988) sobre tempos históricos e tempos biológicos e os problemas da nova ecologia são interessantes: a introdução de uma espécie como o homem. que tem múltiplas relações com outras espécies, em um sistema natural, não aumenta a complexidade do sistema, podendo, pelo contrário, significar a simplificação do mesmo. Os danos sobre o meio ambiente, o incremento descontrolado de algumas espécies, a destruição de ecossistemas inteiros seriam provocados por essa ação "simplificadora" do homem.

Os resultados da ação "simplificadora" do homem sobre os sistemas naturais seriam, portanto: desflorestamento, desertificação, erosão do solo, degradação das terras irrigadas, poluição ambiental e agrícola, aquecimento global, destruição da camada de ozônio, extinção de espécies, emergência de novas doenças.

Tiezzi acrescenta: o homem inventou para si "mutações" para adaptar-se ao meio ambiente, através dos instrumentos científicos e tecnológicos com que se presenteou, falsificando o seu próprio "tempo biológico".

Corroborando a tese da falsificação do próprio tempo biológico pelo homem, citamos as técnicas de fertilização artificial, a liberação de microrganismos geneticamente modificados no ambiente, as variedades engenheiradas de plantas e vegetais.

\section{COMPLEXIDADE E DOENÇAS EMERGENTES}

Para o Grupo de Harvard (Levins et al., 1994), um conjunto de cientistas e profissionais de diferentes áreas de especialização e que se reúne regularmente desde 1991, qualquer análise efetiva de doenças emergentes deve reconhecer no estudo da complexidade, o desafio científico central dos tempos atuais.

De fato, a atual voga em torno da complexidade tem no grupo de físicos do Santa Fe Institute, de Los Alamos, a meca das pesquisas norte-americanas a respeito. A discussão da complexidade, por sua vez, é relacionada à teoria do caos ou o estudo dos sistemas que podem ser alterados, de infinitas e, freqüentemente, imprevisíveis maneiras, a partir de inputs - ou estímulos ou mudanças - mínimos.

Tarride (1994), discorrendo sobre sistemas e complexidade com base em diferentes autores, refere que, na década de 1970, um grupo de matemáticos, físicos, biólogos, transitando em direção à desordem, buscava encontrar os nexos entre diferentes irregularidades presentes na natureza. O estudo do caos constituir-se-ia, desde então, em uma visão transdisciplinar que assume a natureza multidimensional e global dos sistemas.

Para Tiezzi e muitos outros ecologistas, a ecologia é a ciência da complexidade: o caminho da sobrevivência dos sistemas vivos sobre a Terra pode ser não favorecer a futura complexidade do indivíduo e, conseqüentemente, favorecer a manutenção da complexidade dos ecossistemas. Holliday (1983: 51) diz que "a extraordinária característica do processo de seleção natural é que ele pode criar a ordem onde previamente existia o caos, $e, a$ partir de um certo nível de ordem, poderá subseqüentemente criar níveis de complexidade cada vez maiores".

Para Tarride, o paradigma (sic) da complexidade, sem pretender substituir uma maneira clássica de fazer ciência por uma "nova ciência”, produziu o reconhecimento da necessidade de abordar os problemas atuais que afetam ecossistemas e seres humanos, de maneira diferente e complementar à tradicional: é nesse desafio que o pensamento complexifi- 
cador e a modelização sistêmica deverão mostrar toda a sua potencialidade.

O reconhecimento da insuficiência do procedimento de classificar uma dada doença em infecciosa, ambiental, psicossomática, autoimune, genética ou degenerativa, levou o Grupo de Harvard a considerar uma nova doença infecciosa como sendo um fenômeno inesperado, que resulta de múltiplas condições, derivadas de mudanças observadas não apenas no núcleo das células, mas verificadas ao redor de todo o globo terrestre, incluindo mudanças na ecologia, climáticas e nos padrões econômicos.

Verifica-se que o Grupo de Harvard está em busca de uma estratégia de abordagem transdisciplinar que integre parâmetros ecológicos, sociais e biológicos e que compreenda o estudo da complexidade, no conhecimento do fenômeno imprevisível.

Richard Levins, ecologista e geneticista de populações e uma das mais destacadas lideranças acadêmicas do Grupo de Harvard, integrou, nos anos 1970, o grupo de cientistas esquerdistas de Boston, que se intitulava "Grupo de Estudos Sociobiológicos da Ciência para o Povo" e que ganharia fama pelas duras críticas feitas ao livro "Sociobiology: The New Synthesis", do entomologista Edward O. Wilson, da Universidade de Harvard.

Neste livro, Wilson codifica a Sociobiologia como um ramo da Biologia Evolucionária, especialmente da moderna Biologia de Populações que se dedica ao estudo, do ponto de vista biológico, da natureza e das bases do comportamento animal, ou, mais precisamente, do comportamento social animal, contemplando desde as formas mais simples, passando pelos insetos, invertebrados inferiores, mamíferos, primatas e chegando ao Homo sapiens. De acordo com Ruse (1983), seu maior mérito é o esforço de juntar explicação cultural e explicação biológica, na análise do comportamento social humano.

Apesar da virulência das críticas dirigidas a Sociobiologia e, em especial, a Edward O. Wilson, incluindo acusações de nazismo, reacionarismo, visão preconceituosa da mulher e dos homossexuais, a Sociobiologia continua atual. Isto se depreende das pesquisas recentes que tentam comprovar a base genética de certos atributos sociais humanos, como o alcoolismo e a homossexualidade.
Argumentamos que, atualmente, o Grupo de Harvard, nada tem a ver com as polêmicas passadas suscitadas pela Sociobiologia de E. Wilson e de outros autores.

Encontramos, entretanto, uma outra semelhança com o passado nesta busca de um novo marco ou quadro teórico para a história natural das doenças e que seja alternativo aos conceitos de causalidade unidirecional, de causas necessárias e suficientes e de rede de causas. De fato, as atuais preocupações com a complexidade atraem novos interrogantes para o velho problema da causalidade e para os domínios até certo ponto dogmatizados, dos determinantes sócioeconômicos em saúde.

Esse tema foi, e ainda é, objeto de várias propostas teórico-metodológicas geradas, em grande parte, no âmbito do pensamento social em saúde (Arouca, 1975; Goldberg, 1990). Nessa visão crítica, trata-se de introduzir um modelo determinístico, onde um valor político é conferido às variáveis (determinantes) sócioeconômicos: as raízes causais da deterioração da saúde, da ecologia e da sociedade estão fixadas nas contradições internas das estruturas sociais e econômicas prevalecentes.

A estratégia proposta pelo Grupo de Harvard denota, por sua vez, uma grande preocupação com os sistemas adaptativos complexos, pelo fato de as novas doenças infecciosas estarem questionando a previsibilidade implicita em trajetórias ou perfis epidemiológicos paralelos ao processo de desenvolvimento econômico.

A emergência de novas doenças infecciosas está, portanto, fertilizando novas aproximações transdisciplinares, onde somam-se as contribuições de ecologistas marinhos, microbiologistas, epidemiologistas, engenheiros, cientistas sociais e outros especialistas. Em seus esforços, tratam de compreender os sistemas vivos complexos, nos quais se processa a evolução de patógenos desconhecidos ou não.

Nesse novo marco, em um trabalho prévio (Possas \& Marques, 1994), discutimos em que medida a emergência e a disseminação global de doenças infecciosas novas e re-emergentes estão contribuindo para acentuar a complexidade dos perfis de saúde e como esta tendência pode afetar a previsibilidade - ou a capacidade de efetuar prognósticos - implícita nas abordagens predominantes da transição em saúde. O enfoque principal daquele trabalho foi analisar a inade- 
quação das abordagens tradicionais da transição epidemiológica para lidar com essa complexidade. Sugerimos que um enfoque abrangente, transdisciplinar, incorporando as análises contemporâneas da complexidade, baseadas na ecologia, na teoria evolucionária, nas ciências sociais, na ciência da informação, poderia fornecer os elementos para a formulação de um novo quadro de referências teóricas para a transição epidemiológica.

Acreditamos que as suposições clássicas da dinâmica demográfica, a respeito das possíveis conseqüências, no longo prazo, do envelhecimento populacional. do crescimento populacional e da migração, estão sendo abaladas porque desconhecem-se as interações das novas doenças infecciosas com esses processos.

Proliferam atualmente os vaticínios incapazes de dar conta das relações desafiadoras que vão sendo estabelecidas entre mudanças sociais e ambientais e surgimento de novas doenças infecciosas: desequilíbrio ambiental e alterações climáticas, explosão de populações humanas, crescente mobilidade de bens, serviços e pessoas, avanços técnicos, mudanças comportamentais e guerras. Estas mudanças propiciam novos contactos de seres humanos com insetos e animais que são reservatórios de doenças, assim como a criação de novos nichos para agentes de doenças e vetores.

Como interpretar, neste novo contexto global, o surgimento de novas doenças infecciosas? Sem dúvida, a complexidade tem raízes na imprevisibilidade, pois, como efetuar a predição de tendências demográficas e epidemiológicas, ter $100 \%$ de precisão na previsão do curso futuro da fecundidade, da mortalidade, da migração estando diante de fatos incertos e inesperados como o surgimento de novas doenças infecciosas?

\section{ABORDAGEM PROSPECTIVA DA COMPLEXIDADE}

Tem ampla aceitação a suposição de que o conceito de transição epidemiológica deve orientar o planejamento do tipo e da escala das necessidades em saúde que podem ser esperadas no futuro, dentro de diferentes países (Phillips, 1993). Pouco tem servido a esse objetivo, entretanto, os vaticínios determinísticos, com freqüência catastróficos, baseados em perfis epidemiológicos estáticos (Possas \& Marques, I 993).

Alternativamente, por que não supor que antecipações ou projeções dinâmicas, tendo por base diversas conjecturas epidemiológicas, políticas, sociais, mercadológicas, culturais, etc., orientarão melhor, tanto o planejamento dos serviços de saúde quanto a formulação da política científica e tecnológica em saúde?

Aprofundemos esta questão, levantando outra indagação geral: Como abordar o futuro da saúde no mundo e antecipar o que significará para o homem?

Qualquer imagem do futuro é sempre um cenário contendo diversas incertezas, isto é, fatos e acontecimentos que não podem ser antecipados com precisão absoluta. $\mathrm{O}$ futurista canadense Norman Henchey (apud Hancock \& Bezold, 1994), descreve quatro modos de pensar o futuro: o futuro possível; o futuro plausível; a futuro provável; o futuro preferível. O cenário do futuro preferível cria nos indivíduos a expectativa de um valor a ser criado e o do futuro provável permite aos homens preparar-se para enfrenta-lo.

Rattner (1979: 193-194), todavia, chama a atenção para um dos problemas que surgem no caminho dos artífices do futuro: a maioria dos modelos de previsão

“... pressupõe um conhecimento perfeito da realidade, concebida como um sistema cujos elementos necessariamente estariam em harmonia e cujas variáveis dependentes e interdependentes e seus padrões de relacionamento e funcionamento seriam controláveis pelos detentores do poder. Bastaria, então, muda-las ou combiná-las de modo diferente, afim de se conseguir os objetivos almejados. Na realidade, os elementos componentes do sistema estão geralmente em tensão e conflito e é duvidoso que se possa chegar a um conhecimento de todas as variáveis que determinam seu funcionamento e a direção em que evolui o sistema"

Concordamos com Rattner quando argumenta que previsões do futuro baseadas em um tal determinismo histórico, encaram a história 
como um processo linear e progressivo, no qual o homem teria não só a possibilidade de prever o futuro, como o poder de administrá-lo, visando lograr certos fins:

“... planejadores e tecnocratas, amparados por uma visão sistêmica e determinista da sociedade, cuja origem, evolução e destino estariam de acordo com leis, decidem sobre um projeto fundamental... “. (Rattner, 1979: 193)

Contra-argumentamos, porém, que a modelagem sistêmica não é obrigatoriamente determinista e, ao contrário, constitui recurso potencialmente útil, na abordagem da complexidade, cujas raízes estão na imprevisibilidade de certos fatos. Fornece um suporte físico para a formulação de conjecturas no estudo de fatos imprevisíveis como as novas doenças infecciosas.

A seguinte idéia é central nas discussões da complexidade: sistemas adaptativos complexos podem ser quantificados, recorrendo-se com esta finalidade à modelização sistêmica, com suporte nos modelos matemáticos e físicos e na ciência da computação.

Segundo Tarride (1994) a modelização sistêmica situa-se entre os "paradigmas" da concepção de modelos complexos. Nela recorre-se ao conceito de projeção, enquanto que as noções de evidência ou explicação causal lhe são alheias.

De acordo com Tarride, a modelização analítica, ao contrário, é objetiva e se presta à apreensão de fenômenos previsíveis. A modelização sistêmica é projetiva e, segundo Tarride, se desenvolveu precisamente para permitir passar da previsibilidade forçada do cálculo à imprevisibilidade.

Uma análise prospectiva, sendo uma atividade projetiva, constitui, portanto, uma tarefa distinta da predição de fatos previsíveis. Enquanto a prospectiva diz respeito à antecipação, a predição requer um grau de certeza dificilmente alcançado na realidade.

De fato, as palavras predição/previsão são sinônimas que têm por significados: profecia; vaticínio; prognóstico. Ou seja, o resultado da previsão ou predição, é um vaticínio, uma profecia ou prognóstico.

A palavra prospectiva, por sua vez, diz respeito a fazer projeções no futuro. É concernente à construção de uma imagem crítica do futuro, de uma conjectura.

Ambas - previsão e prospectiva - tratam de olhar em direção ao futuro, tarefa que é por definição interdisciplinar, pluralística e de complementaridade. Se, entretanto, a predição estabelece prognósticos, a prospectiva faz conjecturas sobre o futuro.

Com efeito, a confrontação de previsões feitas no passado, com a realidade populacional atual, mostra divergências que têm a ver com a ocorrência do inesperado, como certos eventos migratórios ou certos progressos sanitários - científicos, tecnológicos - que costumam surpreender, com seus impactos, podendo tanto ultrapassar expectativas como rejeitar hipóteses (Arocena, 1993). O desvio entre a evolução esperada e a evolução real, pode oferecer, por exemplo, uma medida do grau de inovação tecnológica da medicina, no período coberto pela projeção.

Essa perspectiva crítica permitiu identificar particularidades e especifcidades e graças a ela hoje já se compreende que, com base em um prognóstico demográfico único, linear, é muito difícil conjecturar diante do incerto, do novo. Arocena fornece alguns exemplos interessantes: a Suécia e outros países do Norte da Europa evidenciam um surpreendente crescimento da fecundidade, indicando que sociedades hiperdesenvolvidas estão retornando às pautas familiares tradicionais, contrariando as previsões lineares dos enfoques dominantes da transição demográfica. No que se refere à mortalidade, encontram-se desde previsões de esperança de vida de 125 anos, até vaticínios catastróficos para as perspectivas ambientais e climáticas e para as doenças infecciosas.

É, portanto, a imprevisibilidade que nos autoriza a pensar diferentes cenários alternativos e analisar imagens prospectivas do futuro, baseadas no nosso conhecimento do presente. Ao construir conjecturas sobre diferentes possibilidades, poderemos colaborar para evitá-las ou, ao contrário, para torná-las realidade. Portanto, já que os desenvolvimentos populacionais são, inerentemente, incertos e os fenômenos migratórios, assim como as doenças emergentes, são especialmente imprevisíveis -, pensamos que os cenários pros- 
pectivos podem tornar se uma valiosa alternativa teórico-metodológica.

A efetuação de uma análise prospectiva será, necessariamente, um exercício formal, processado em um marco temporal e contingencial bem determinado e que recorrerá a diversas técnicas de antecipação. Tratar-se-á de esboçar e analisar um certo número de diferentes futuros e de construir conjecturas a respeito, com uma finalidade prática: auxiliar a tomada de decisões, a escolha, a fixação de prioridades, analisando diferentes trajetórias epidemiológicas, mantendo, de início, uma certa distância de todas elas. Este distanciamento é necessário para contornar o viés do determinismo, para o qual Keilman (1986: 52) chama a atenção: "certas projeções de populações nacionais, por se basearem em modelos determinísticos incapazes de lidar com a incerteza, acabam sendo instrumentos das políticas autoritárias".

Em síntese, a prospectiva é, essencialmente, uma atitude que olha-para-a-frente e que toma em conta, entre outros aspectos, o fato de que a oferta de certas formas de cuidados à saúde pode requerer prazos longos de implementação. Tomemos, a título de exemplo, a construção de cenários relacionando problemas de saúde de indivíduos idosos, como câncer e doenças cardiovasculares, a diferentes estilos de vida. Esta tarefa requer a formulação prévia de perguntas, como no exemplo seguinte:

\section{"No futuro, quais são os principais desenvolvimentos que influenciarão o status de saúde dos idosos na Holanda, entre 1984 e 2000?" e "Quais são os padrões alternativos de serviços de saúde mais importantes, entre 1984 e 2000, tendo-se em consideração o futuro status de saúde dos idosos e o número relativo dos mesmos na população da Holanda?" (Becker et al., 1986: 16)}

No caso das novas doenças infecciosas, buscar-se-á o fortalecimento e a modernização, no curto prazo, dos serviços de notificação e vigilância epidemiológica.

Embora os estudos do futuro no campo da saúde sejam ainda embrionários e em pequeno número (IHFN, 1994), diversas técnicas e procedimentos formais são amplamente utilizados no campo da prospectiva tecnológica. Entre outros, a elaboração de cenários (árvores de relevância), os métodos de consenso (Delphi, painéis de especialistas, sessões de brain storm), as análises estrutural e morfológica, as análises de impactos cruzados, a análise de insumo/produto, as técnicas de prognóstico, de simulação, de mapeamento contextual, as árvores de decisão (Godet, 1987; Rattner, 1979).

Consideramos também os Sistemas de Informação Geográfica - SIGs, um suporte físico de enorme potencial na análise prospectiva. De introdução recente no estudo das doenças infecciosas, os SIGs incorporam técnicas de geoprocessamento, imagens fornecidas por satélites e tecnologia de sensoriamento remoto.

A introdução de SIGs poderá revigorar a geografia médica, ao definir, com alta precisão, as condições topográficas e meteorológicas associadas com a abundância de parasitas (Dobson \& Carper, 1993; Epstein et al., 1993). A visualização cartográfica de dados e informações detalhadas e diversas, ajuda, portanto, a construir conjecturas epidemiológicas, sobretudo tendo em conta a emergência de doenças infecciosas.

Através de modelos explanatórios preditivos da difusão da doença, a geografia médica tem pretendido oferecer concepções ecológicas integradoras da rede causal: dado um conjunto de condições antecedentes, identifica-se um padrão, reconhecem-se relações causais e efetua-se a predição do fenômeno resultante. Diante do imprevisível, porém, seus propositores também não escapam à tentação de resvalar para os vaticínios.

Pretendendo superar a geografia médica tradicional, a ecologia política da doença surgiu para analisar certas relações "escondidas" entre economia, política e o fenômeno observável. Conferindo relevância aos fatores políticos e econômicos na explicação da distribuição da doença, examina o ambiente em seu contexto social e político: o Estado e as relações sociais exercem influências sobre o ambiente e a doença. O propósito da ecologia política da doença, a causa estando tanto na estrutura social quanto no microorganismo (Mayer, 1992), é estabelecer os determinantes econômicos, sociais e políticos da doença. Contempla, portanto, um alargamento da interpretação da causação; seu con- 
ceito de causa é multifacético, incluindo comportamentos, ambiente, cultura, sociedade e germe patogênico. Esta maneira ampliada de ver a doença, coloca, entretanto, a predição da doença como um dos seus objetivos principais. Nesse particular, a ecologia política converge com os argumentos essenciais da epidemiologia crítica latino-americana, embora focalizando menos a crítica das noções de causalidade e dirigindo mais seus argumentos para registrar a predominância da análise acrítica das interações doença-ambiente. Falta lhe faz, a nosso ver, a perspectiva histórica que a análise prospectiva poderá impulsionar.

\section{A INTERVENÇÃO DEMOCRÁTICA}

Conforme descreve Bifani (1993), da aplicação (difusão) da ciência e tecnologia no sistema social e na natureza, resulta uma miríade de efeitos diretos e indiretos, em diferentes espaços funcionais e físicos e que se materializam em diferentes horizontes temporais. Tanto o sistema social quanto a natureza, não sendo passivos, reagem a esta aplicação e o resultado é que a ação interventora original da ciência e da tecnologia inicia uma dinâmica complexa de efeitos e reações que são cada vez mais amplos, tanto em intensidade, como em extensão temporal e espacial, com fenômenos sinergéticos amplificando os impactos finais. Em conseqüência, a predição da probabilidade de ocorrência (risco) destes efeitos e reações, bem como da magnitude dos mesmos, se torna cada vez mais difícil, aumentando assim a incerteza.

Efeitos e reações inesperados - não necessariamente negativos - que podem permanecer ocultos ou escondidos e se infiltrar na totalidade das estruturas sociais, econômicas, políticas e culturais, bem como na natureza, costumam escapar, ou melhor, podem deixar de ser considerados pelos processos de tomada de decisão nas atividades de formulação de políticas, planejamento, gestão e controle do desenvolvimento científico e tecnológico. Sendo esta uma situação indesejável e incômoda, que caracteriza a omissão diante do fenômeno oculto e/ou imprevisível, torna-se justificado o exercício de conjecturar sobre a ocorrência do inesperado. A fixação de prioridades de pesquisa e a escolha tecnológica passarão a ser, portanto, atividades antecipatórias, tão capazes de tomar em conta os riscos de ocorrência de efeitos previsíveis, quanto de conjecturar sobre a imprevisibilidade.

A análise prospectiva, encarando o futuro como devenir, tem por finalidade contribuir para o diálogo democrático em uma sociedade (Martínez, 1993; Arocena, 1993). De fato, esta propriedade decorre do fato de ligar-se à decisiva questão da democratização do conhecimento científico. Ao tomar em conta expectativas individuais e coletivas, pode impulsionar diálogos abertos e pluralísticos e suscitar o interesse social em torno de grandes opções vinculadas ao futuro.

Pode contribuir para aumentar a consciência pública a respeito das consequiências éticas e de segurança do desenvolvimento científico e tecnológico, estimulando uma nova interação entre ciência, tecnologia, natureza e humanidade.

\section{FINALIZANDO}

No presente estudo, argumentamos que a abordagem prospectiva, além de assumir que a emergência de novas doenças infecciosas é um processo evolucionário complexo, no qual interagem diversos processos naturais e sociais (Eckardt, 1994), também deverá ter em conta que o tempo é uma variável arisca e que opera segundo diferentes racionalidades.

Enfatizamos que a análise das novas doenças infecciosas deve ir ao encontro do estudo da complexidade. É a imprevisibilidade das novas doenças infecciosas que conduz a este reconhecimento.

Para o enfrentamento da imprevisibilidade propusemos a realização de estudos críticos do futuro em saúde, contemplando a modelização sistêmica, os encontros transdisciplinares e a utilização de sistemas de informação geográfica, no monitoramento global das novas doenças infecciosas. Uma estratégia, enfim, que efetue conjecturas sobre o futuro, alimentada por dados e informações gerados pelo monitoramento ecológico, geográfico e evolucionário.

Essa estratégia compreenderá: análises prospectivas de curto-prazo, através do reconhecimento das condições que favorecem a reemergência ou o recrudescimento de doenças 
já conhecidas e pela antecipação de mudanças ecológicas associadas à atividade humana; análises prospectivas de longo-alcance, por meio de modelos baseados na ecologia evolucionária.

Finalmente, consideramos que a análise prospectiva será potencialmente útil aos processos democráticos de formulação das políticas públicas, quando novas formas de interação entre ciência, tecnologia e dinâmica evolutiva estiverem sendo cogitadas.

\section{RESUMO}

\section{MARQUES, M. B. Doenças Infecciosas Emergentes no Reino da Complexidade: Implicações Para as Políticas Científicas e Tecnológicas. Cad. Saúde Públ., Rio de Janeiro, 11 (3): 361-388, jul/set, 1995.}

A atual emergência e re-emergência de algumas doenças infecciosas ultrapassa fronteiras nacionais, afetando cada vez mais países desenvolvidos e em desenvolvimento. Este estudo alienta que a disseminação global de novas doenças infecciosas está afetando a previsibilidade implícita nos enfoques dominantes da transição em saúde. Este trabalho analisa, do ponto-de-vista epistemológico e político, enfoques alternativos para enfrentar estas novas tendências epidemiológicas globais.

Palavras-Chave: Virus; Doenças Infecciosas; Parasitas Humanos; Transição Epidemiológica; Complexidade

\section{REFERÊNCIAS BIBLIOGRÁFICAS}

AROCENA, R., 1993. Acerca de la prospectiva (desde algunos países de América Latina). In: Estrategias, Planificación y Gestión de Ciencia y Tecnologia (E. Martinez, org.), pp. 185-289, Caracas: Cepal-ILPES/Unesco/UNU/CYTEDD/Editorial Nueva Sociedad.

AROUCA, A. S. S., 1975. O Dilema Preventivista. Contribuição para a Compreensão e Crítica da Medicina Preventiva. Tese de Doutorado, Campinas: Faculdade de Ciências Médicas, Universidade Estadual de Campinas.

BARBOUR, A. G. \& FISH, D., 1993. The biological and social phenomenon of Lyme disease. Science, 260: 1610-1616.
BECKER, H. A.; KLAASSEN-VAN DEN BERG JETHS, A.; KRAAN-JETTEN, A. \& RIJSSELT, R. VAN, 1986. Contextual scenarios on the elderly and their health in the Netherlands In: Methods and Experience in Impact Assessment (H. A. Becker \& A. L. Porter, orgs.), pp. 15-50, The Netherlands: D. Reidel Publishing Company.

BERKELMAN, R. L.; BRYAN, R. T.; OSTERHOLM, M. T.; LEDUC, J. W. \& HUGHES, J. M., 1994. Infectious disease surveillance: a crumbling foundation. Science, 264: 368-370.

BERLINGUER, G., 1993. The interchange of disease and health between the old and new worlds. International Journal of Health Services, 23: 703-715.

BIFANI, P., 1993. Cambio tecnológico y política científica y tecnológica. In: Estrategias, Planificación y Gestión de Ciencia y Tecnologia (E. Martinez, org.), pp. 99-123, Caracas: Cepal-ILPES/Unesco/UNU/ CYTED-D, Editorial Nueva Sociedad.

CDC (Centers for Disease Control and Prevention), 1994. Addressing Emerging Infectious Disease Threats: a Prevention Strategy for the United States. Georgia: NCID/CDC.

COIMBRA, T. L. M.; NASSAR, E. S.; BURATTINI, M. N.; SOUZA, L. T. M.; FERREIRA, I. B.; ROCCO, I. M.; ROSA, A. P. A. T.; VASCONCELOS, P. F. C.; PINHEIRO, F. P.; LEDUC, J. W.; RICO-HESSE, R.; GONZALEZ, J. P.; JAHRLING, P. B. \& TESH, R. B., 1994. New arenavirus isolated in Brazil. The Lancet, 343: 391-392.

DOBSON, A. \& CARPER, R., 1993. Biodiversity. The Lancet, 342: 1096-1099.

DOLL, R., 1993. Health and the environment in the 1990s. American Journal of Public Health, 82: 933-941.

ECKARDT, I., 1994. Challenging Complexity. Conceptual issues in an approach to new diseases. In: Disease in Evolution. Global Changes and Emergence of Infections Diseases (M. E. Wilson; R. Lewis \& A. Spielman, eds.), vol. 740. pp 408-417, New York: Annals of the New York Academy of Sciences.

EPSTEIN, P. R.; ROGERS, D. J. \& SLOOFF, R., 1993. Satellite imaging and vector-born disease. The Lancet, 341: 1404-1406.

FAS (Federation of American Scientists), 1993. Public Interest Report, 46 (6) November/December.

GALLOPIN, G., 1992. Science, technology and the ecological future of Latin America. World Development, 20: 1391-1400. 
GEISSLER, E., 1993. Strengthening the biological weapons convention by the biesenthal vaccine initiative. In: Biotechnology R\&D Trends. Science Policy for Development (G. T. Tzotzos, org.), pp. 43-52, New York: Annals of the New York Academy of Sciences.

GEORGOPAPADAKOU, N. H. \& WALSH, T., 1994. Human mycoses: drugs and targets for emerging pathogens. Science, 264: 371-373.

GODET, M., 1987. Scenarios and Strategic Management. London: Butterworth Scientific Ltda.

GOLDBERG, M., 1990. Este obscuro objeto da epidemiologia. In: Epidemiologia. Teoria e Objeto (D. C. Costa, org.), pp. 86-136, São Paulo: Hucitec/Rio de Janeiro: Abrasco.

HANCOCK, T. \& BEZOLD, C., 1994. Possible futures, preferable futures. Health Care Forum Journal, 23-29.

HAYES, M. V., 1992. On the epistemology of risk: language, logic and social science. Social Science and Medicine, 35: 401-407.

HOLliDAY, R., 1983. A Ciência do Progresso Humano. Belo Horizonte: Itatiaia/São Paulo: Universidade de São Paulo.

IHFN (International Health Futures Network), 1994. Healthcare 2000: Developments in Policy, Strategy and Technology. Proceedings of the $4^{\text {th }}$ Annual Meeting of the International Health Future Network, May 25-28. The Netherlands: Garderen \& Utrecht. (Mimeo.)

IOM (Institute of Medicine), 1992. Emerging Infections: Microbial Threats to Health in the United States. Washington, DC: National Academy Press.

JAIN, S. C., 1991. Global health: emerging frontier of international health. Asia Pacific Journal of Public Health, 5: 112-114.

KEILMAN, N., 1986. The unpredictability of population. In: Methods and Experiences in Impact Assessment (H. A. Becker \& A. L. Porter, orgs.), pp. 49-80, The Netherlands: D. Reidel Publishing Company.

LEVINS, R.; TAMARA, A.; BRINKMANN, U.; ECKARDT, I; EPSTEIN, P.; MAKHOUL, N.; POSSAS, C. A.; PUCCIA, C.; SPIELMAN, A. \& WILSON, M., 1994. The emergency of new diseases. American Scientist, 82: 52-60.

MARQUES, M. B., 1991. Ciência, Tecnologia, Saúde e Desenvolvimento Sustentado. Rio de Janeiro: Fundação Oswaldo Cruz. (Série Política de Saúde, 11)

MARTíNEZ, E., 1993. Planilicación y gestión de ciencia y tecnología. In: Estrategios, Planificación y Gestión de Ciencia y Tecnología (E. Martinez, org), pp. 503-515, Caracas: Cepal-ILPES/UNESCO/ UNU/CYTED-/Editorial Nueva Sociedad.

MAYER, J. D., 1992. Challenges to understanding spatial patterns of disease: philosophical alternatives to logical positivism. Social Science and Medicine, 35: 579-587.

MORSE, S. S., 1993. Emerging Viruses and their Causes. New York: The Rockfeller University. (commisioned review article, mimeo.)

PHILLIPS, D. R., 1993. Urbanization and human health. Parasitology, 106: S93-S107.

POSSAS, C. A. \& MARQUES, M. B., 1994. Health transitions and complex systems: a challenge to prediction? In: Disease in Evolution. Global Changes and Emergence of Infectious Diseases (M. E. Wilson; R. Levins \& A. Spielman, orgs.), vol. 740, pp. 285-296, New York: Annals of The New York Academy of Sciences.

RATTNER, H., 1979. Estudos do Futuro: Introdução à Antecipação Tecnológica e Social. Rio de Janeiro: Fundação Getúlio Vargas.

RUSE, M., 1983. Sociobiologia: Senso ou ContraSenso? Belo Horizonte: Itatiaia/São Paulo: Universidade de São Paulo. (O Homem e a Ciência, 13)

SKOLE, D. \& TUCKER, C., 1993. Tropical deforestation and habitat fragmentation in the Amazon: satellite data from 1978 to 1988. Science, 260: 1905-1910.

SMITH, A., 1986. Saúde para todos no ano 2000? In: Para uma Nova Ciência, pp. 171-192, Lisboa: Gradiva.

TARRIDE, M. 1., 1994. Complejidad y Sistemas Complejos. Trabalho apresentado à Escola Nacional de Saúde Pública da Fundação Oswaldo Cruz, Rio de Janeiro. (Mimeo.)

TIEZZI, E., 1988. Tempos Históricos, Tempos Biológicos. A Terra ou a Morte: os Problemas da Nova Ecologia. São Paulo: Nobel.

WALSH, J. F.; MOLYNEAUX, D. H. \& BIRLEY, M. H., 1993. Deforestation: effects on vectorborne disease. Parasitology, 106: S55-S75. 


\section{Debate sobre o Artigo de Marques \\ Debate on the Paper by Marques}

\section{Ana Lucia S. Sgambatti de Andrade Instituto de Patologia Tropical e Saúde Pública Universidade Federal de Goiás}

Inqüestionável a oportunidade do tema "Doenças infecciosas emergentes no reino da complexidade: Implicações para as políticas científicas e tecnológicas", abordado por Marília B. Marques. A recente re-emergência do vírus Ebola no Zaire é o testemunho mais recente da relevância deste tema, que vem desencadeando sucessivas discussões, "convocando" as nações, ricas e pobres, para uma cooperação técnica, visando a definição e a operacionalização de estratégias para o enfrentamento das doenças infecciosas emergentes. Na ordem do dia, novamente, "the burden of infectious diseases". A Organização Pan-americana da Saúde prevê uma corrida sanitária de não menos que uma década e mais de U\$200 bilhões para se controlar, por exemplo, a pandemia de cólera na América Latina (CDC, 1994).

Inúmeras seriam as possibilidades de abordagem do tema. No entanto, Marília B. Marques inova em sua leitura crítica dos desdobramentos previsíveis em direção a uma era de imprevisibilidade, se me permite o trocadilho, tendo em vista as doenças infecciosas emergentes. $\mathrm{O}$ artigo traz contribuição, aprofundando a discussão das doenças emergentes no contexto de um processo evolucionário complexo. Enfatiza as dificuldades em se propor intervenções, dado o caráter de imprevisibilidade dessas doenças. Talvez o texto pudesse ser enxugado; alguns traços pecam pela redundância. No subtópico Complexidade e Doenças Emergentes, por exemplo, a polêmica do Grupo de Harvard (páginas 11 a 15) poderia ser condensada.

A profundidade e a abrangência do artigo deixam pouco a acrescentar. Embora reconhecendo não ter sido objetivo do artigo descrever detalhadamente a geografia das doenças infecciosas emergentes, observa-se que a seção $\mathbf{O}$ Problema é, na sua maior parte, dedicada a exemplos de doenças emergentes no contexto da realidade epidemiológica dos Estados Unidos. Neste balanço de novas ondas de agentes infecciosos letais, a maré vem desaguando, cada vez mais, em algumas regiões brasileiras. Julgamos oportuno, à guisa de contribuição, a lembrança de duas outras doenças infecciosas emergentes detectadas em regiões da Amazônia brasileira nos últimos meses. Como já se sabe, os municípios da região norte do estado de Mato Grosso vêm apresentando acelerado e abrupto desenvolvimento de mudanças no uso da terra, com devastações ecológicas, gerando um cenário ecoepidemiológico onde o homem vem compartilhando seu espaco com vetores e reservatórios de focos de doenças infecciosas. Acrescem-se a esse quadro os freqüentes deslocamentos populacionais na área. Assim é que, em 1994, surge a primeira descrição da presença do vírus da hepatite E no Brasil, nessa região. A notificação de uma "epidemia de hepatite" em adultos jovens, com $10 \%$ de legalidade, motivou a condução de um inquérito soroepidemiológico, que foi realizado em 98 garimpeiros da região de Peixoto de Azevedo, detectando-se $6 \%$ de soropositividade ao vírus da hepatite E (Pang et al., 1995). Ainda no mesmo ano, epidemiologistas de Mato Grosso relataram morte súbita de três recém-nascidos residentes em áreas próximas à mata, nos arredores da cidade de Sinop, e em abril de 1995, outras três mortes ocorreram em Cuiabá com manifestações clínicas compatíveis com Síndrome pulmonar por hantivirus. Os exames sorológicos confirmaram tratar-se de hantivírus (dados não publicados).

É premente a necessidade do fortalecimento e da modernização, no curto prazo, dos serviços de notificação e vigilância em saúde, ajustados ao conceito de doenças infecciosas emergentes, aspectos estes também explorados no texto. Aqui vale mencionar que a abrangência do conceito de doença emergente inclui, no elenco de possibilidades, desde novas doenças cujos agente são desconhecidos até velhas doenças com nova epidemiologia. Os Estados Unidos, por exemplo, têm aumentado a vigilân- 
cia das doenças parasitárias consideradas exóticas. Como exemplo, a ocorrência de dois casos de doença de Chagas aguda, em conseqüência de transfusão de sangue de doador assintomático, imigrante da América Latina, motivou um editorial no Annals of Internal Medicine intutilado is Trypanosoma cruzi a new threat to our blood supply? (Kirchhof, 1989).

Dentre vários pontos levantados no artigo, algumas palavras a propósito das potencialidades dos Sistemas de Informação Geográfica (SIG) na análise prospectiva, conforme sugerido por Marília Marques. Um dos grandes avanços da informática no campo da vigilância espacial no controle de endemias tem sido o uso dos SIG. Para doenças emergentes cujo controle depende da ordenação do processo de desenvolvimento social e econômico e de ocupação do espaço, a utilização de ferramentas como o SIG viabiliza o monitoramento e o planejamento de ações de controle. O mapeamento geográfico segundo características geológicas e hidrográficas e o mapeamento da agricultura e da ocupação do meio ambiente têm permitido o mapeamento da expansão de infecções emergentes, por exemplo, na Amazônia brasileira. Recursos corriputacionais têm sido utilizados para sobrepor imagens de satélite a dados epidemiológicos representados graficamente, para a composição de imagens tridimensionais interpondo o ambiente, o homem e a fonte de vetores. Esta estratégia tem possibilitado a identificação de criadouros de mosquitos, descrição de ecótopos, tipos de vetores e predição de dispersão de doenças em áreas ainda virgens de colonização. Esta metodologia vem, há algum tempo, sendo utilizada com sucesso em doenças parasitárias, como malária e oncocercose.

$\mathrm{Na}$ era "internética", como todo bom usuário, não poderia deixar de mencionar a potencialidade da rede internet para viabilizar o estabelecimento de informações "superhighways", adicionando eficiência na troca/disseminação de informações com a finalidade de vigilância de doenças emergentes. Um banco de dados internacional de doenças infecciosas, integrado a sistemas já existentes, com protocolos comuns e armazenados em formatos compatíveis, facilitaria o acesso de usuários de todo o mundo. Nesse aspecto, os CDC vêm pro- pondo o estabelecimento de uma Rede de Vigilância Sentinela, interligada eletronicamente, implementando as tradicionais fontes de dados utilizadas (CDC, 1994).

Em análise presente e futurista deste excitante tema, e considerando que a comunicação entre os povos está em escala irreversivelmente crescente, o destaque fica para o conceito de "saúde internacional" contrapondo-se à noção de "saúde nacional".

\section{REFERÊNCIAS BIBLIOGRÁFICAS}

CDC (Centers for Disease Control and Prevention), 1994. Addressing Emerging Infectious Disease Threats: A Prevention Strategy for the United States. Atlanta: U.S. Departmente of Health and Human Services, Public Health Service.

KIRCHHOFF, L. V., 1989. Is Trypanosoma cruzi a new threat for our blood supply?. Annals of Interna! Medicine, 111: 773-775.

PANG, L.; ALENCAR, F.; CERUTTI, C.; MILHOU,, W. K.; ANDRADE, A. L. S. S.; OLIVEIRA, R. M.; KANESA-THASAN, N. \& HOKE, C., 1995. Hepatitis E in the Brazilian Amazon. American Journal of Tropical and Hygiene, 52: 347-348.

\section{Alexandre da Costa Linhares Instituto Evandro Chagas \\ Fundação Nacional de Saúde}

Entendemos que o trabalho apresentado traduz, essencialmente, uma profunda e abrangente reflexão acerca de um tema da atualidade de alcance universal, qual seja o das doenças infecciosas emergentes. Destaca-se a complexidade da questão, à luz de um enfoque prospectivo, ressaltando-se o fator imprevisibilidade do panorama nosológico como limitante quanto à eficácia de medidas que contenham a escalada de patógenos novos para a ciência, bem como daqueles cuja importância, até recentemente, era subestimada.

Em recente publicação, Henderson (1994) assinala que a efetiva prioridade antes atribuída pelos órgãos oficiais de saúde, médicos em geral e pesquisadores às doenças infecciosas foi deslocada para os processos crônico-degenerativos. Como reflexo dessa condição, ressalta o autor, a própria importância e abrangência de unidades e divisões da Organização Mundial da 
Saúde (OMS), relacionadas a patologias como a tuberculose, a lepra e outras, foi sensivelmente reduzida. É notória a ênfase conferida ao fortalecimento dos programas de imunização, como recurso para deter o avanço das doenças infecciosas emergentes. $\mathrm{O}$ "recente e dramático" reaparecimento do sarampo nos Estados Unidos, por exemplo, bem denota a aparente insuficiência, mesmo nos países desenvolvidos, da prática rotineira de vacinação.

A título de sugestão, recomendamos que a autora amplie as informações sobre a ocorrência da síndrome pulmonar ocasionada pelo hantavírus no sudoeste dos EUA. Tal evento, assim admitido, bem caracterizou a relativa ineficiência dos serviços oficiais de saúde desse país, no manejo de epidemias causadas por "novas" doenças infecciosas (Gellert, 1994).

Também caberia certo destaque, assim entendemos, ao uso indiscriminado de antibióticos, daí resultando cepas bacterianas resistentes a múltiplas drogas, como os pneumococos no seio hospitalar e enterococos não-sensíveis à vancomicina (Marwick, 1995).

Em âmbito nacional, julgamos merecer particular ênfase a multiplicidade de arbovírus que se mantêm em ciclos enzoóticos na região amazônica, infectando tangencialmente o homem que entra em contato com a mata. São 183 vírus diversos, 157 dos quais isolados pela primeira vez no Brasil, e, importante, 87 destes novos para o mundo. Nesse contexto, destaquem-se 34 agentes capazes de infectar o homem (Vasconcelos et al., 1992).

\section{REFERÊNCIAS BIBLIOGRÁFICAS}

HENDERSON, D. A., 1994. Journal of Infectious Diseases, 170: 284-285.

GELLERT, A. G., 1994. Nature, 370: 409-410.

MARWICK, C., 1995. JAMA, 273: 189-190.

VASCONCELOS, P. F. C et al., 1992. Ciência e Cultura, 44: 117-124.

\section{Maria Hortal}

Dpto. de Laboratorios de Salud Publica

Ministerio de Salud Publica - Uruguay

El manuscrito de M. B. Marques titulado "Doenças Infecciosas Emergentes no Reino da Complexidade: implicações para as políticas científicas e tecnológicas" plantea una problemática presente y futura relacionada con la aparición y reaparición de agentes infecciosos que reviste gran interés y actualidad. La discusión ilustra la complejidad e imprevisibilidad de esos fenómenos, que inesperadamente han planteado y plantearan a nivel mundial nuevos desafios para las politicas de salud, asi como la necesidad de adecuar la epidemiología de transición tradicional (Almeida-Filho, 1992; Veronelli et al., 1994). Los nuevos agentes infecciosos surgen tanto en países desarrollados como en países en desarrollo, vinculados a gran diversidad de variables interactuantes, que condicionan combinatorias de infinitas posibilidades, entre el individuo, los microorganismos, y factores sociales, económicos, políticos, ecológicos.

Como microbiólogo, la lectura del trabajo de Marquez nos enfrenta a una complejidad biosocial, la que apenas intuímos en toda su dimensión, y nos reafirma en reflexiones sobre la trascendencia de algunas comprobaciones. Por ejemplo, al profundizar en la biología molecular de varios agentes, hemos percibido causas de cambio en la historia natural de las enfermedades infecciosas, resultante de un comportamiento diferente de patogenos infecciosos frecuentes. A este respecto se ha tenido que reformular conceptos referidos a enfoques epidemiológicos y terapéuticos. Es motivo de preocupación la creciente resistencia a los antibióticos de muchas bacterias tradicionalmente sensibles, y la falta de respuesta a drogas antivirales de varios grupos de virus (Cohen, 1994). La capacidad de variación de los microorganismos es muy grande. Existen mutantes resistentes de muchas bacterias, pero tambien la resistencia la pueden adquirir por intercambio genético intra e interespecies como en los casos citados de $S$. pneumoniae y de enterococos (Coffey et al., 1991). El manejo inadecuado de los antibióticos contribuye como um factor selectivo, favoreciendo, paradójicamente, la proliferación de las bacterias resistentes (Levy, 1992).

Si bien los virus gripales (ej. A/Beijing/32/ 92) varien anualmente sus antigenos de 
superfície, y periodicamente surjan cepas con cambios mayores en sus estructuras externas capaces de provocar pandemias, no les incluímos en el grupo de los patogenos emergentes o reemergentes, por cuanto es un problema muy conocido, para lo cual la Organización Mundial de la Salud, ya hace varias décadas, ha montado un sistema de vigilancia a nivel mundial, lo que permite una rápida caracterización de los nuevos tipos y con ellos preparar vacunas para la prevención específica de la infección (Ghendon, 1994).

Sucede algo similar con el virus respiratorio sincicial, un patogeno de gran impacto en la infancia, que también experimenta variación anual, la que estaria condicionada por muchos factores (Hortal et al., 1993), incluyendo Ias presiones selectivas ejercidas por el estado inmunitario de Ias poblaciones (Garcia et al., 1994).

Las publicaciones especializadas en medicina humana con frecuencia documentan el hallazgo de nuevos agentes etiológicos, y los medios de difusión masiva, cada vez más; se interesan por su aparición. Recientemente la prensa mundial difundió noticias aterradoras sobre una virosis altamente letal, registrada en algunas localidades del Zaire. Sucesos de esta naturaleza nos enfrentan a posibles catástrofes provocadas por agentes infecciosos que limitan la confianza generada por el êxito obtenido con la erradicación de la viruela, o con la interrupción de la transmisión dei poliovirus salvaje en ias Américas. El microbiólogo no puede permanecer ajeno a nuevos riesgos potenciales, aparte de los mencionados, como 1a posibilidad de que, con el correr dei tiempo, otros agentes puedan llenar el nicho ecológico dejado libre por microorganismos que han podido ser controlados o erradicados. La analogía se observa en el hombre: cuando alteramos su flora residente, muchas veces el disbalace ocasionado permite la implantación de un patogeno.

No cabe duda de que, en todos los países o regiones, han aparecido nuevas enfermedades infecciosas, u otras ya presentes han cobrado especial relevancia. Estas circunstancias han llevado a los laboratorios federales de los EEUU a efectuar un llamado de atención tendiente a incluir en sus esquemas organizativos, y en los de instituciones de salud de otros países, recursos que les permitan intensificar la vigilancia, y reconocer e identificar rápidamente a las nuevas patologías infecciosas (CDC, 1994). Acompanamos este llamado de atención y, en lo limitado de nuestra area de acción, nos plegamos a las propuestas incluídas en el trabajo que comentamos. Se requiere estar técnicamente actualizados, para poder identificar precozmente a agentes emergentes o reemergentes, y asi contribuir a una vigilancia efectiva, tanto en el plano nacional como internacional.

No debemos, además, abandonarei estudio de los agentes conocidos, sino por el contrario intensificar la exploración de todas sus potencialidades biológicas. Al igual que cuando se dispuso de terapias antibióticas, y pareció que el problema de las enfermedades infecciosas estaba superado, debemos recordar que los recursos biológicos de los microorganismos, como los de todo ser vivo, no se agotan sino que subsisten y encuentran mecanismos para sobrevivir.

\section{REFERENCIAS BIBLIOGRAFICAS}

ALMEIDA-FILHO, N., 1992. Epidemiología sin números. Paltex $\mathrm{N}^{\circ}$. 28, OPS.

VERONELLI, J. C.; NOWINSKI, A.; HARRETCHE, A. \& ROITMAN, B., 1994. La Salud de los Uruguayos: OPS/Nordan-Comunidad.

COHEN, D. M., 1994. Acyclovir resistant, pathogenic herpesviruses. Trends in Microbiology., 2: 481-484.

COFFEY, T. J.; DOWSON, C. G.; DANIELS, M., et al., 1991. Horizontal transfer of multiple penicillin-binding protein genes, and capsular biosynthetic genes, in natural populations of $S$. pneu moniae. Molecular Microbiology, 5: 2255-2260.

LEVY, S. B., 1992. The Antibiotic Paradox: How Miracle Drugs are Destroying the Miracle. New York: Plenum.

GHENDON, Y., 1994. WHO principies of influenza strain selection. PBRV. Research Group News letter, 2: 3-4.

HORTAL, M.; MANY, M.; RUSSI, J. C. \& CHIPARELLI, H., 1993. Meteorological variables and occurrence of respiratory syncytial virus in Uruguay. Research in Virology, 144: 405-408. 
GARCIA, O.; MARTIN, M.; DOPAZO, J. \& ARBIZA, J. et al., 1994. Evolutionary pattern of human respiratory syncytial virus (subgroup A): cocirculating lineages and correlation of genetic and antigenic changes in the G glycoprotein. Journal of Virology, 68: 5446-5459.

CDC (Centers for Disease Control and Prevention), 1994. Addressing Emerging Infectious Disease Threats: a Prevention Strategy, for the United States. Atlanta: U.S. Dept. of Health and Human Service.

\section{Judith Kardos Moetzel}

Instituto de Medicina Tropical de São Paulo Universidade de São Paulo

O artigo é muito oportuno. A grande questão é como implementar na prática estratégias que contemplem o imprevisível. A discussão multidisciplinar e a análise prospectiva em muito contribuem para uma reflexão e interação sobre parâmetros não conhecidos.

Porém um dos maiores obstáculos a uma ação efetiva, além da inércia e do conservadorismo, é o limite de recursos. Assim, as políticas públicas necessariamente priorizam os problemas prementes presentes e os previsíveis, relegando, via de regra, a segundo plano aqueles com os quais não nos deparamos de imediato. Além disso, há uma natural resistência em aceitar evidências ainda frágeis de alterações epidemiológicas, quando temos toda uma tradição de pesquisadores renomados que, eventualmente, indicam o contrário.

Dentro do campo da malária, os exemplos são inúmeros. Entre a Segunda Guerra Mundial e a década de 60, acreditava-se que o problema da malária estava praticamente resolvido, com a eficácia dos novos quimioterápicos e dos inseticidas. Não se previa o aparecimento da resistência aos mesmos. A própria Organização Mundial da Saúde, a muito custo, mantinha financiamento de pesquisa de vacinas, o que só foi reforçado depois de nova ascensão da endemia na década de 70. No Brasil, a situação da malária foi ainda agravada com a abertura de novas fronteiras e com o desmatamento.

No começo do século, as observações cuidadosas e o conhecimento multidisciplinar de Adolfo Lutz ligaram a malária emergente na região da construção da estrada de ferro São Paulo-Santos à existência de bromélias e à re- produção de Kerteszia em suas folhagens. Esta correlação foi contestada por muito tempo por pesquisadores americanos, que não concebiam a malária autóctone em região montanhosa e muito menos aceitavam o reconhecimento de novo vetor (Gadelha, 1994). Só muito depois os achados de Adolfo Lutz foram validados.

Para contornar o problema das bromélias como criadouros de anofelinos, lançou-se mão não só de sua retirada manual e de controle químico, mas, o que parece inconcebível hoje em dia, da destruição pura e simples das florestas próximas a centros urbanos, como medida profilática da malária (Gadelha, 1994).

No Estado de São Paulo, instituídas várias medidas de erradicação da malária seguidas de rigorosa vigilância epidemiológica, aparentemente bem-sucedida, temos, no momento, dados sorológicos que indicam a existência de quantidade insuspeita de malária autóctone, sem que haja número substancial de casos relatados. Há suspeita de malária simiana circulando na região, sem afetar o homem clinicamente (Curado et al., 1994). O que isto representa de risco para o futuro? Qual a prioridade de pesquisa sobre este assunto? Como justificar a destinação de técnicos de campo e de veículos, quando estes são limitados e existem problemas prementes como a ameaça das mais variadas viroses, a expansão do Aedes aegypti, o combate a focos de dengue. Que parte dos recursos alocar para pesquisar hipotéticas endemias? Qual é o impacto futuro que elas poderão ter? Como fazer com que se aceitem novos conceitos?

Outro exemplo: na Amazônia, o Anopheles darlingi é considerado o principal vetor de malária, sendo que algumas outras espécies também têm sido incriminadas. Recentemente pudemos demonstrar que, em certa região do Acre, a espécie predominante de anofelino era Anopheles oswaldoi (Branquinho et al., 1993). Este anofelino não era considerado até então como vetor, e apenas um ou outro exemplar infectado havia sido encontrado, ocasionalmente, por outros pesquisadores. Há localidades no Acre com alta prevalência de malária, onde os únicos anofelinos que encontramos infectados eram A. oswaldoi. Não só havia circunstâncias quase incontornáveis para dar continuidade à pesquisa local sobre o assunto, 
como também os colaboradores que participaram da captura e do trabalho prático não aplicavam, até há pouco, medidas de prevenção de maneira sistemática em locais onde não encontravam A. darlingi, já que os recursos são escassos e os conceitos anteriores ainda predominam.

Concluindo, além de discussões multidisciplinares, de reconhecimento do imprevisível, na prática seria necessário que, como política de Saúde Pública, fosse destinado sistematicamente percentual dos recursos, mesmo que pequeno, ao controle e à pesquisa de assuntos de importância, aparentemente, secundária no momento.

\section{REFERÊNCIAS BIBLIOGRÁFICAS}

GADELHA, P., 1994. From "Forest malaria" to "Bromeliad malaria": a case-study of scientific controversy and malária control. Parasitologia, 36: 175-195.

CURADO, I.; MALAFRONTE, R. S.; MARRELLI, M. T.; BRANQUINHO, M. S. \& KLOETZEL, J. K., 1994. Investigações de malária no Vale do Ribeira. Baixada Santista e Litoral Norte. Revista da Sociedade Brasileira de Medicina Tropical, 27 (Supl. I): 266.

BRANQUINHO, M. S.; TAIPE-LAGOS, C. B.; ROCHA R. M.; NATAL, D.; BARATA, J. M. S.; COCHRANE, A. H.; NARDIN, E.; NUSSENZWEIG, R. S. \& KLOETZEL, J. K., 1993. Anophelines in the state of Acre, Brazil, infected with Plasmodium falciparum, $P$. vivax, the variant $P$. vivax $\mathrm{VK} 247$ and $P$. malariae. Transactions of Royal Society of Tropical Medicine \& Hygiene, 87: 391-394.

\section{Marcos Boulos \\ Faculdade de Medicina Universidade de São Paulo}

O artigo, baseado em extensa revisão, propõe, para enfrentar a imprevisibilidade, a "realização de estudos críticos do futuro em saúde, contemplando a modelização sistêmica, os encontros transdiciplinares e a utilização de sistemas de informação geográfica, no monitoramento global das novas doenças infecciosas".

A tentativa de prever o caminhar da humanidade, em todas as suas facetas, depara-se com a absoluta incompetência do modelo científi- co para prever dados que não "respeitam" os modelos que procuramos construir.

Tentar colocar a evolução humana em "fórmulas" que possam prever o próximo passo é, no meu modo de entender, a tentativa de robotizar o mundo animal, transformando-o em previsível.

Devemos ter em mente que a ciência somente nos últimos tempos faz parte do conhecimento humano acumulado, e que o modelo científico, de grande utilidade na biomedicina, onde permitiu o desenvolvimento de modelos que facilitaram a compreensão da patogenia das doenças, e, principalmente, levou a aperfeiçoamento do diagnóstico, falha quando procura prever comportamentos que não são equacionáveis. $\mathrm{O}$ modelo científico, por exemplo, é de pouca utilidade para prever a evolução de uma infecção sob tratamento.

Exemplificando mais, $30 \%$ dos pacientes com meningite pneumocócica morrem a despeito do tratamento adequado e a tempo instituído. Outro exemplo: paciente com infecção pelo vírus da hepatite B pode ter evolução variável, podendo causar icterícia ou não; pode haver cura em 2, 3, 4, 5 ou 6 meses; pode evoluir para cronicidade com surgimento de cirrose hepática; pode evoluir para hepatocarcinoma; pode ter evolução fulminante com o paciente em poucos dias morrendo; o paciente pode, ainda, ser portador do vírus da hepatite $\mathrm{B}$ e nunca vir a desenvolver hepatite.

Com o desenvolvimento da psiconeuroimunologia, o modelo científico começa a mostrar o que de há muito os médicos "percebiam": que fatores emocionais estão diretamente relacionados ao surgimento de doenças por ação no sistema hipotálamo-pituitário-adrenal.

Outro fator que merece destaque é o fato de que muitas doenças começam a ser diagnosticadas pelo surgimento de técnicas laboratoriais, antes inexistentes. Isto não significa que estas doenças são novas, mas apenas que agora estão sendo diagnosticadas.

Se novas doenças surgem, outro tanto desaparece, mantendo, provavelmente, o nível de doenças igual no transcorrer do tempo.

O ressurgimento de determinadas doenças está, muitas vezes, associado a com oscilações no investimento em saúde pública. Exemplo é o reaparecimento da difteria na Rússia, que, durante anos, não vacinou suas crianças contra esta 
infecção. Como prever as mudanças sociais que freqüentemente ocorrem na humanidade?

Baseado no exposto, considero que a tentativa de modelização de fatos imprevisíveis está fadada a ser de pequeno valor prático e social a despeito da grande importância teórica que possa vir a ter.

Esta é a contribuição que um médico clínico, habituado a trabalhar na imprevisibilidade da relação microorganismo-hospedeiro, pode dar.

\section{Pedro Luiz Tauil}

\section{Departamento de Saúde Coletiva Universidade de Brasília}

Indiscutivelmente, o texto é um estímulo intelectual. A partir da discussão sobre o surgimento de novas doenças infecciosas, não previsto no modelo clássico da transição epidemiológica que vem orientando as políticas de saúde de países desenvolvidos e também de alguns subdesenvolvidos, nos últimos anos, a autora nos leva a considerar as limitações do nosso poder de previsão e expõe a alternativa de projetar o futuro com base na imprevisibilidade que leva em conta a complexidade da abordagem dos diferentes elementos que estão envolvidos na produção e desenvolvimento de agravos à saúde.

No que se refere às doenças infecciosas emergentes e suas conexões com o tráfico global de viroses (Morse, 1993) e o intercâmbio de doenças entre o velho e o novo mundo (Berlinguer, 1993), parece-me importante acrescentar o transporte de insetos vetores de doenças entre países. Já no final da década de 30, o Nordeste brasileiro foi infestado pelo Anopheles gambiae procedente da África, responsável por uma das mais graves epidemias de malária ocorridas no mundo, com letalidade superior a 10\%. Recentemente, em 1985, os Estados Unidos foram infestados pelo Aedes albopictus, transmissor do dengue e de vários tipos de encefalites na Ásia, transportados em pneus usados procedentes do Japão. No ano seguinte, o Brasil registrou, também, a presença deste mosquito, que já infesta todos os estados da Região Sudeste e que já é identificado também em outras regiões do país. Apesar de, até o momento, não ter sido respon- sabilizado por transmissão natural de alguma doença, é fator de risco muito importante para diferentes doenças, algumas delas inusitadas no continente americano.

Do ponto de vista da intervenção para prevenir agravos, sem dúvida, os desafios da imprevisibilidade levam a limitações importantes. Resta ao setor saúde, muitas vezes, apenas a possibilidade de sua detecção precoce para limitação dos danos, resultado de vigilância epidemiológica eficaz, o que infelizmente não é uma prática rotineira. Um exemplo recente foi a epidemia de dengue no Sul da Bahia que, por várias semanas, foi diagnosticada como de rubéola, atrasando a aplicação de medidas de controle. A atenção para agravos inusitados, dentro de um sistema de vigilância epidemiológica, é uma prática complexa porém de muita utilidade, se não para prevenir o aparecimento de novas doenças, para eventualmente limitar sua abrangência. Na competição por escassos recursos, as medidas preventivas de possíveis agravos levam desvantagem política em relação aos agravos já existentes e conhecidos, por serem estes mais prementes. A previsão de transmissão de dengue no Brasil, após mais de 50 anos sem sua ocorrência, foi feita por técnicos do Ministério da Saúde com muitos anos de antecedência, porém os recursos necessários para a redução da infestação vetorial, particularmente para o Estado do Rio de Janeiro, para onde se previu a epidemia, nunca foram autorizados.

O aparente paradoxo ente o sucesso evolutivo do homem e o aumento da incerteza sobre seu futuro pode ser visto como a demonstração da importância da teoria da complexidade, base do entendimento da imprevisibilidade, modelo teórico que permite a identificação de diferentes situações futuras e não apenas de uma única predeterminada e inexorável. O malthusianismo não levou em consideração a capacidade científica e tecnológica do homem para aumentar significativamente a produção de alimentos, emitindo previsão, que felizmente não se configurou, de colapso do abastecimento. O problema hoje é de desigualdade na oferta de alimentos, não de capacidade de produção, pois esta é suficiente para toda a população mundial e tende a crescer com o desenvolvimento da genética. 
A síntese dos avanços dos conhecimentos em diferentes especialidades - ecologia, sociologia, biologia, informática - para benefício da humanidade como um todo, é o desafio fundamental. Como obtê-la em um desenvolvimento analítico e isolacionista dos diferentes ramos da ciência, criando até mesmo linguagens incompreensíveis fora dos respectivos âmbitos? Será que a formação de grupos transdiciplinares, que periodicamente se reúnem, como o de Harvard, citado pela autora, pode dar conta desta síntese? Ou é preciso que a transdiciplinaridade seja praticada no momento mesmo do trabalho científico?

\section{REFERÊNCIAS BIBLIOGRÁFICAS}

BERLINGUER, G., 1993. The interchange of disease and health between the old and new worlds. Intemational Journal of Health Services, 23: 703-715.

MORSE, S. S., 1993. Emerging Viruses and their Causes. New York: The Rockfeller University. (Commisioned review article, mimeo.)

\section{José Carlos Serufo}

Núcleo de Pesquisa e Apoio Diagnóstico Universidade Federal de Minas Gerais

Aos cientistas ligados à área da saúde talvez sejam aqueles de quem mais se deva cobrar um posicionamento claro a respeito das questões políticas, ou seja, do estudo profundo acerca dos sistemas políticos e suas implicações na qualidade de vida de todo o planeta, especialmente do ser humano.

Isto para não cairmos em erros de simplificação, muitas vezes expressos em textos científicos de formulação erudita, mas que todavia tergivesam, apresentando uma análise esterilizada das implicações dos avanços tecnológicos, dos desflorestamentos, das guerras, da ação predatória do homem em relação à natureza, do empobrecimento da qualidade de vida da população, como se fossem fatos ocorridos ou provocados pela humanidade, fruto de uma "desorganização" ou desconhecimento, e não pela decisão de governos, de interesses políticos e econômicos, sobre os quais a maioria das populações de todos os países não têm a menor responsabilidade, uma vez que não são chamadas a colaborar nas decisões, mas pelo contrário, são mantidas mal-informadas ou desinformadas com o intuito de que não os percebam e não reajam.

É um escândalo político, econômico e social o reaparecimento de doenças como a cólera e a tuberculose que, sabemos, ocorrem como consequiência da deterioração das condições de vida das populações.

A dengue é um bom exemplo da falência do modelo de controle de vetores, centrado no uso de inseticidas em larga escala que faz dos "países periféricos" clientes cativos da indústria de pesticidas cuja lógica desconsidera a agressão ao meio ambiente e os distúrbios para o ecossistema e para a saúde das pessoas que essa prática resulta. $\mathrm{O}$ investimento em educação resolveria este problema em caráter definitivo. E por que não é feito? Certamente que uma população que tem conhecimento para resolver o problema da dengue seria também capaz de compreender outras coisas e de exigir amplamente seus direitos.

Da mesma forma, doenças como a AIDS não podem ser enfrentadas sem se atacar a questão social, a questão moral, especialmente a cultural. Ou seja, sendo uma doença que não afeta apenas as populações carentes, a AIDS põe a nu a falsa moral das classes dominantes que incentivaram ao longo dos séculos a ignorância, o desconhecimento do próprio corpo, em todas as camadas sociais, sendo essa, sem dúvida, uma das principais causas da proliferação das doenças sexualmente transmissíveis.

Desta maneira, se queremos dar um enfoque epistemológico, não há como discutirmos a emergência e a re-emergência de doenças infecciosas sem levarmos em conta esta abordagem, sem nos pronunciarmos sobre as questões políticas mais emergentes, nacional e internacionalmente.

É impossível deixar de enfocar o papel que têm cumprido organismos internacionais como a ONU, que mostra nem sempre se direcionar pelas boas intenções de enfrentar os "novos desafios, e de redirecionarmos as agendas de pesquisa e escolha de tecnologias estratégicas"(vide texto).

A discussão sobre a previsibilidade do risco de ocorrência de eventos, longe de orientar a 
intervenção no rumo do controle e da erradicação das doenças, tem servido muito mais à propaganda dos planos de saúde e ao comércio, com sucateamento da saúde pública, exacerbada em tempos de política neoliberal.

Torna-se necessário realizar uma análise profunda e responsável da situação da saúde. onde esta questão deveria ser vista como uma questão social e não como um mercado valioso de venda de medicamentos, aparelhos e insumos para diagnóstico de doenças evitáveis.

Creio ser necessário um posicionamento aberto e corajoso da comunidade científica para denúncia dos abusos. dos escândalos, dos infanticídios cometidos com a fome, a miséria e as guerras. que ceifam a vida de milhares de seres humanos todos os anos, mas que não têm sido a preocupação dos governos e de muitos que crêem, enganosamente, não serem estes motivos de risco universal e, portanto, não os relacionam com as doenças emergentes e reemergentes.

Sabemos, e não podemos fugir à responsabilidade de divulgar, que é possível alterar com a ação humana as condições pré-históricas ainda vividas pela maioria esmagadora da humanidade. Ao discutirmos a ecologia, é fundamental que nos lembremos que não são os homens e mulheres de todos os países os que desmatam, os que queimam, os que matam os rios e destroem os ecossistemas, e sim aqueles movidos pela ganância, cuja satisfação imediata e selvagem de seus desejos é seu único compromisso.

Assim, para discutirmos "desequilíbrio ambiental e alterações climáticas, explosão de populações humanas, crescente mobilidade de bens, serviços e pessoas, avanços técnicos, mudanças comportamentais e guerras" é fundamental que nos posicionemos politicamente no sentido de interferir na política global do nosso país e internacionalmente, pois a "imprevisibilidade" não é assim, como pode ser observado nos exemplos acima e no texto, tão imprevisível quanto alguns querem fazer crer.

Parabéns à autora do texto "Doenças Infecciosas Emergentes no Reino da Complexidade: Implicações para as Políticas Científicas e Tecnológicas", que enriquece essa discussão indo além da relação agente-hospedeiro, saindo da ótica da mídia atual, que veicula uma imagem onde os micróbios ressurgem como grandes vilões e estão ameaçando toda humanidade. $\mathrm{O}$ caminho é este, atacar a questão, buscar todos os seus ângulos, apontar as causas que se julgam verdadeiras, sem medo de errar ou de ser criticado. Parabéns, também aos Cadernos de Saúde Pública.

\section{Hermann G. Schatzmayr \\ Instituto Oswaldo Cruz \\ Fundação Oswaldo Cruz}

O trabalho apresenta a complexidade dos fatores envolvidos no aparecimento de novas entidades mórbidas ou no ressurgimento de antigas, sob formas mais graves.

Inicialmente cumpre assinalar que o fenômeno não é novo, as epidemias de varíola, cólera, peste e influenza, em passado histórico não tão distante, com efeitos por vezes devastadores, indicam que, em presença de populações susceptíveis, estes agentes tiveram a possibilidade de atingir grandes núcleos populacionais.

Os avanços no conhecimento das etimologias das doenças infecciosas, de seu diagnóstico, e da vacinação contra várias delas, criaram a falsa impressão de que estavam sob controle e que seriam rapidamente superados eventuais focos que surgissem.

Esqueceram-se, porém, dois fatos biológicos irreversíveis: um, a evolução dos seres vivos, incluindo as mutações dos microorganismos, gerando melhores condições de sobrevivência para alguns indivíduos e, outro, o crescimento demográfico exponencial das populações humanas neste século.

Este último dado, sem qualquer cunho alarmista, nos indica que, em muitas regiões do mundo, já não há mais possibilidade sequer de se prover saneamento básico para as populações existentes, pelas tecnologias atuais, por falta de recursos hídricos sustentáveis a longo prazo. Parece-nos que este crescimento demográfico é citado apenas ao longo do texto e não como uma das bases do processo em discussão.

A pressão das populações crescentes sobre os recursos naturais existentes, inclusive sobre áreas e sistemas ecológicos ainda não desenvolvidos, na busca de bens ou mesmo da simples sobrevivência, é muito forte. A par disso, ocor- 
rem as ocupações de larga escala, desenvolvidas por estruturas poderosas como, por exemplo, na busca de minério ou na implantação da agricultura ou da pecuária.

Estas atividades freqüentemente expõem populações humanas a ciclos naturais de agentes infecciosos até então em equilíbrio e afastados do homem.

Por outro lado, já se afirmou que nada tem sentido em biologia se não for avaliado pela ótica da evolução; as mutações aleatórias propiciam condições de vantagem para alguns indivíduos, os quais, ao sobreviverem melhor às condições existentes, predominam sobre os demais. Ocasionalmente a resistência a drogas ou a maior capacidade de se multiplicarem em seus hospedeiros, o que podemos chamar de maior virulência, surgem ao longo do processo e são a base do estabelecimento de novas entidades ou do ressurgimento de outras já conhecidas.

$\mathrm{O}$ artigo descreve as possibilidades de previsão dos cenários futuristas, reconhecendo o grau de imprecisão dos mesmos, com o que concordamos.

O artigo preconiza, ainda, uma conjugação de esforços de várias áreas do conhecimento, visando uma ação comum, com o que também se concorda, inteiramente.

Parece-nos, no entanto, muito mais importante, em vez de tentar prever o imponderável, nos voltarmos ao instrumentalismo, destacandose o estabelecimento de métodos e tecnologias de monitoramento global do surgimento de problemas. Estes sistemas deveriam permitir detectar, em qualquer parte do mundo, o acúmulo de quadros de doenças emergentes ou disto suspeitas, bem como acompanhar a evolução do problema ao longo do tempo.

A par do monitoramento de eventos, será necessário, a nível global, o aprimoramento de ações de controle que possam ser aplicadas, de maneira consistente, em todas as populações sob risco imediato ou de médio e longo prazo.

Dentro destas ações de controle, destaca-se a capacidade de mobilização de grupos de abordagem especializados, apoiada na tríade epidemiologia, laboratório e clínica, para desenvolver ferramentas de diagnóstico e prevenção.

Outra ação instrumental importante é a correta divulgação de informações sobre estes quadros emergentes, hoje tratados na mídia comercial de forma quase sempre sensacionalista no momento em que surgem e em seguida esquecidos, quando mais se necessitaria de uma avaliação crítica da situação, a médio e a longo prazos.

Destaca-se, ainda, a necessidade de maior flexibilidade e rapidez na alocação de fundos e a definição de prioridades, para se fazer face a esses desafios; não se pode esperar anos para que mais recursos fluam para doenças que, em poucos meses, possam ter efeitos graves sobre populações.

Em resumo, em nossa opinião, o artigo é estimulante e abrangente, porém não enfatiza os dois principais agentes do surgimento de doenças novas c o ressurgimento de antigas, de forma mais grave, quais sejam, a evolução biológica e o crescimento demográfico humano.

Procurando o macro dos fatores envolvidos, acaba deixando sem maior definição os instrumentos a aplicar.

$\mathrm{O}$ artigo permite que se reavalie que espécie de profissional necessitamos formar para a Saúde Pública de nossos dias; a volta de enfoque mais instrumentalista, que norteou, por exemplo, a nossa Ensp por muitos anos, deve ser repensada.

Através da pura dialética, muitas vezes ela própria conflitante e perplexa pelas rápidas mudanças que surgiram nos últimos anos no mundo, não seremos capazes de responder a graves problemas que, eventualmente, atinjam milhões de pessoas, em curto prazo de tempo.

\section{Paulo Gadelha}

Casa de Oswaldo Cruz

Fundação Oswaldo Cruz

O artigo de Marília Marques vem em boa hora. A atualidade do tema, seu tratamento sob a ótica da complexidade e da construção de alternativas metodológicas voltadas para a intervenção no campo da saúde despertam grande interesse, sendo a qualidade do texto incentivo adicional para estimular novas reflexões. Alertamos inicialmente que nossos comentários não terão o sentido de cobrar o atendimento de questões que o artigo não se pro- 
pôs a desenvolver, mas apenas apontar para aspectos que poderiam precisar melhor a pauta proposta. Face às limitações de espaço, nos restringiremos a algumas questões conceituais e a chamar a atenção sobre a contribuição que os trabalhos históricos têm dado a esse debate.

O surgimento e desaparecimento de doenças infecciosas, tema marcante na historiografia sobre doenças, recebeu tratamento mais abrangente em 1930, com a obra de Charles Nicolle, "Naissance, Vie et Mort des Maladies Infectieuses". Nicolle se interroga sobre o destino das doenças infecciosas, fornecendo explicações para exemplos históricos, e especula sobre o futuro tomando como referencial as interações parasitas-hospedeiros e o fenômeno de mutação. Suas questões são de grande atualidade, como podemos depreender, para citar um exemplo, do seguinte comentário (op. cit, p. 129):

"Il Y aura donc des rnaladies nouvelles. C'est ura fait fatal. Un autre fait, tout aussi fatal, est que nous nes auroras jamais les dépister dès leur origine que, lorsque nous era auroras notion, elles seront déjà toutes forniées, adultes pourait-ora dire (...). il faut donc aussi bien se résignier à l'ignorance des premiers cas évidents. Ils séront méconus, confondus avec des maladies déjà existants et ce n'est qu'après une longue période de tâtonnements qu'on dégagera le nouveau type pathologique du tableau des affections déjà classées."

Desde então, e especialmente a partir da década de 70, contribuições fundamentais para o tema surgiram da interface entre estudos bioecológicos e históricos, a exemplo dos conceitos de unificação microbiana do mundo (Le Roy Ladurie, 1973); imperialismo ecológico, gradiente epidemiológico e processo civilizatório (Crosby, 1986 e McNeil, 1976), e patocenose (Grmek, 1983), que se relacionam às referências recentes de Marília Marques a Morse - "tráfico global de viroses" - e Berlinguer - "intercâmbio de doenças entre o velho e o novo mundo" (p. 3). Uma maior familiaridade com essas vertentes teria enriquecido o texto em pauta.

$\mathrm{O}$ conceito de doenças emergentes, por exemplo, veio substituir na historiografia a noção mais restrita de doença "nova". Nesse sen- tido, o artigo de Marília Marques ganharia mais nitidez caso utilizasse a categorização proposta por Mirko Grmek onde são identificadas cinco situações em que uma doença pode ser considerada emergente: existência prévia, mas ocultada pela impossibilidade de sua conceitualização no passado; mudança qualitativa ou quantitativa que a tornam mais perceptível; introdução a partir de outras regiões; presença anterior restrita aos animais e, finalmente, radicalidade da emergência no sentido em que os agentes ou as condições para sua existência não existiam antes de suas primeiras manifestações clínicas (Grmek, s/d). Além da referência genérica à incidência de doenças, previamente reconhecidas ou não, e do caso específico de disseminação para outras áreas, citados no texto, ficariam melhor evidenciadas relações com novas formas de percepção e conceitualização, mudanças qualitativas e a diferença entre "novidade" e "emergência".

Quanto às explicações adiantadas para a emergência de doenças, acreditamos que o artigo poderia ser também enriquecido. Embora enfatize em vários trechos a complexidade desse fenômeno, referindo-se especialmente ao Grupo de Harvard, fica a impressão de que a autora valoriza um referencial ecológico mais restrito, relativo à ocorrência de variantes gênicas e/ou contatos com novos nichos em função da degradação de ecossistemas, em detrimento de questões referentes à modificações tecnológicas e conceituais na construção de nosologias, aspectos culturais e comportamentais e mecanismos de sinergia e antagonismo entre doenças. Mesmo quando alguns desses fatores são mencionados (p. 16), é imediatamente reforçada a idéia de novos contatos com reservatórios e vetores.

Sentimos falta também do desenvolvimento de conceitos que procurem organizar sinteticamente os vários fatores citados como causas do fenômeno da emergência. Lembramos novamente neste caso Mirko Grmek e seu conceito de patocenose, onde a freqüência e a distribuição de cada doença em situações de equilíbrio dependem, além de componentes endógenos e ecológicos, da frequiência e distribuição de todas as outras doenças. É assim que verifica-se sempre a existência de um pequeno número de 
doenças muito freqüentes convivendo com grande número de doenças raras. Certamente o conceito de patocenose é passível de críticas que não podem ser aqui consideradas. De qualquer maneira, sua utilização demonstrou-se pregnante na interpretação da emergência de doenças em momentos de ruptura de "equilíbrio patocenóticos" ao longo da história e foi utilizado por seu autor no debate sobre a emergência (e não "novidade") da AIDS, seguido do apoio de autores como Luc Montaigner (1994) e contrapondo-se, com vantagens, a interpretações reducionistas centradas na hipótese de mutação e novos contatos (Grmek, 1989).

Finalmente, quanto à variabilidade de microorganismos, teria sido oportuno mencionar, na medida em que os aspectos de detecção e vigilância são enfatizados, os desafios colocados pelo reconhecimento de novas formas virais ou sub-virais (prions e virions) e sua relação com doenças emergentes (Chastel, 1992).

Há outro aspecto geral do texto que nos aventuramos a comentar e que se refere à questão da complexidade. Aqui o artigo é de grande riqueza quando relaciona delineamentos gerais dessa temática com as diferenças entre predição/prognóstico e projeção/conjecturas e suas consequiências no estudo das transições epidemiológicas, intervenção na saúde pública e diálogo democrático. Causou-nos a impressão, entretanto, de que o aspecto geral da imprevisibilidade, que dá o mote para considerações sobre temporalidade/risco e a defesa de abordagens prospectivas mereceria maior contextualização. A referência a outras chaves, algumas delas anunciadas nas pp. 11 e 12 (sistemas estáveis e instáveis; ordem, desordem e autoorganização; local, global e história e irreversibilidade) tornaria mais claras as diferenças entre o entendimento da probabilidade no sentido clássico e seu papel nos sistemas instáveis ou a relação entre capacidade preditiva, "leis do caos" e "leis da natureza" que se expressam, por exemplo, na assertiva de que "probabilidade não é ignorância e de que a ciência não se confunde com a certeza" (Prigogine, 1994).

Por sua vez, consideramos um ponto forte o alerta, citando Tarride, de que o paradigma da complexidade não pretende fundar uma "nova ciência" (p. 12). Vale a pena reforçar com Edgar
Morin (1990) que a complexidade não "produz" nem "determina" a inteligibilidade, mas fixa uma estratégia dialógica que, entre outros efeitos, estabelece uma tensão entre a totalidade como verdade e não-verdade (Morin, 1990). A complexidade, portanto, não deve inibir o esforço de interpretações totalizantes. Sob essa perspectiva ficam mais claras as relações entre predição, conjecturas e abertura para o imprevisto.

\section{REFERÊNCIAS BIBLIOGRÁFICAS}

CHASTEL, C., 1992. Histoire des Vírus. De la Variole au SIDA. Paris: Édit. Boubée.

GRMEK, 1989. Histoire du Sida: Début et Origine d'une Pandémie Actuelle. Paris: Payot.

, 1993. Le concept de maladie émergente.

Historv and Philosohhy of the Life Sciences, 15:281-296

, s/d. Décline et émergence des maladies.

História, Ciências, Saúde-Manguinhos, vol. II, n. 2. (no prelo)

MONTAIGNER, L., 1994. Des Vírus et des Hommes. Paris.

MORIN, E., 1990. Science avec Conscience. Paris: Fayard.

PRIGOGINE, I., 1994. Les Lois du Chaos. Paris: Flammarion.

\section{Henrique Rattner}

Associação Brasileira para o

Desenvolvimento de Lideranças

O tema "incertezas e riscos em saúde decorrentes de mudanças tecnológicas" proporciona o ensejo para analisarmos criticamente não somente algumas diretrizes da política científico-tecnológica em saúde, mas também as propostas recorrentes de introduzir modelos sistêmicos e abordagens transdisciplinares no estudo dos múltiplos e complexos fatores associados à irrupção de novas doenças. Essa abordagem facilitaria a construção de um referencial teórico mais abrangente para se estudar a dinâmica de patologias, e, assim, contribuiria à previsibilidade e à eficácia das políticas de saúde.

Há, contudo, um aspecto fundamental a ser considerado: os estudos sobre doenças e saúde concentram-se quase exclusivamente em sua 
patogenese biológica, enquanto todas as evidências apontam para processos complexos de inter-relações entre fatores biológicos, materiais, sociais e psíquicos. São esses últimos que, a nosso ver, desencadeiam os fenômenos de anomia social e que tornam o convívio na sociedade insustentável.

A tese que associa a emergência de novas patologias à inovação e generalização do uso de tecnologias permite várias análises e inferências.

Tanto na alopatia quanto na agricultura, são conhecidos e multiplicam-se os fenômenos de patologias ou infecções cujos agentes são resistentes a antibióticos ou pesticidas aplicados amplamente.

O próprio envelhecimento das populações, ou melhor, o aumento gradual da expectativa de vida conseguido, ao longo de décadas, com melhor alimentação, higiene e tratamentos de saúde, tem trazido à tona e elevado a incidência de uma série de doenças degenerativas, objeto de novas pesquisas e estudos.

A tese presta-se, contudo, a uma incursão em área pouco explorada, porém de relevância ímpar para compreensão dos problemas humanos de nossa civilização e para seu equacionamento e superação mediante políticas públicas adequadas.

Inovações tecnológicas - enquanto alavanca poderosa da expansão, do crescimento e da diversificação das atividades econômicas -, têm resultado na eliminação incessante de postos de trabalho, supostamente de menor qualificação. Por outro lado, a criação de novos empregos, ainda que melhor remunerados, não tem permitido a absorção dos "redundantes", ou desempregados, pela estrutura produtiva.

Entre as conseqüências desse processo, apontam-se as perdas dos assalariados em sua participação na renda nacional e a deterioração geral da qualidade de vida de camadas crescentes da população, mesmo nos países desenvolvidos. Os impactos mais graves e duradouros, dificilmente identificáveis por um raciocínio causal linear, mas perfeitamente perceptíveis mediante uma abordagem analítica sistêmica e interdisciplinar, se verificam na paulatina destruturação do tecido social, através da marginalização e segregação de inúmeros indivíduos com plena capacidade produtiva, declarados inúteis e rejeitados pela sociedade. Aos impactos diretos expressos na pauperização física e material dessa multidão incontável, devem ser acrescentados os efeitos psíquicos e morais, expressos no comportamento individual, e seus reflexos na psique coletiva. Os excluídos, ao perder a estima própria e a dos outros, e sem meios de reagir ou inverter esse processo, tornam-se agressivos e transgressores da lei e, desmotivados e desesperançosos, procuram refúgio na doença mental ou, no caso extremo, no suicídio.

Por outro lado, o avanço impetuoso das tecnologias de ponta nos sistemas de produção industriais - a automação e robotização - têm resultado em crescente dicotomização dos processos de trabalho, entre concepção/planejamento e execução, destituída essa última de qualquer compreensão do conjunto e, portanto, de sentido das tarefas realizadas.

Acompanhando o noticiário sobre os inúmeros casos de perturbação psíquica e emocional, bem como as estatísticas assustadoras sobre as violências cometidas nos grandes centros da civilização urbano-industrial, fica a dúvida sobre a relação "custos/benefícios" do progresso técnico.

\section{Nestor Oscar Stanchi}

Facultad de Ciencias Veterinarias Universidad Nacional de la Plata

He leído con atención el trabajo "Doenças Infecciosas Emergentes no Reino da Complexidade: Implicações para as Políticas Científicas e Tecnológicas" encontrando muy interesantes los conceptos vertidos por la autora.

Me gustaría agregar que, dentro de los ejemplos mencionados en el citado artículo, llama la atención la ausencia de enfermedades producidas por Rickensias, en especial las del grupo de las Fiebres Manchadas e incluso las del Genero Ehrlichia, especialmente en pacientes HIV positivos.

Por otro lado, las consideraciones expresadas apuntan al conocimiento del futuro como modelo de previsión que, en la práctica, ha mostrado aciertos y desaciertos com responsabilidades no siempre bien delimitadas, tanto para uno como para otro caso. La autora 
expresa la necesidad de la "modelización sistémica", en la cual incluye también estudios del comportamiento social humano. Estos cambios de comportamiento pueden hacer muy complejo un estudio de esta naturaleza, ya que, según las circunstancias, podría ser uno de los factores que aporten más imprevisibilidad entre todos los analizados. Ante estos datos, parecería ser más apropiado un análisis de las perspectivas a corto plazo que aquellas de largo plazo, debiendo por tanto establecerse algún parámetro de certeza estadística para los distintos modelos, para lograr analizar mejorel futuro de las enfermedades emergentes. Sin embargo, el análisis a largo plazo seria el que mejor podría establecer la estrategia de previsión de enfermedades en función de Ia humanidad.

No hay que olvidar que las enfermedades multifactoriales son los principales problemas en la actualidad y que, en definitiva, la modelización constituye una ayuda valiosa para un mayor conocimiento de las mismas.

\section{O AUTOR RESPONDE / THE AUTHOR REPLY}

O artigo mereceu comentários críticos de natureza variada. Devido ao predomínio, entre os comentaristas indicados pelos Cadernos de Saúde Pública, de profissionais das áreas biomédica e clínica, seria mesmo de esperar que o texto cumprisse o papel de estimular a divulgação, para um público mais amplo, de informações e dados, verdadeiramente preciosos do ponto de vista acadêmico, sobre a situação das doenças emergentes/ re-emergentes no Brasil. Tenho testemunhado que há, nos círculos internacionais dedicados ao assunto, grande expectativa e preocupações motivadas pela escassez de informações sobre a situação em nosso País.

As contribuições vieram, portanto, em muito boa hora. Considerando a quase inexistência de dados e informações a respeito circulando no Brasil, as ocorrências referidas por Sgambatti de Andrade, Linhares, Hortal, Kloetzel, Boulos e Tauil, certamente, enriquecem o conhecimento a respeito e fazem aflorar, para o espaço das preocupações com a saúde pública, graves e pouco valorizados episódios de doenças emergentes e re-emergentes. As informações trazidas por Linhares, sobre as arboviroses na região amazônica, atestam a liderança internacional alcançada por pesquisadores brasileiros.

Situações, epidêmicas ou não, como as descritas por Sgambatti de Andrade, no Estado do Mato Grosso do Norte - Hepatite E, em garimpeiros e hantavírus, em recém-nascidos em geral, terminam sendo "metabolizadas" cientificamente pelos meios acadêmicos e pela indústria farmacêutica do Primeiro Mundo, muito antes de que qualquer política científica específica, ou até mesmo de saúde, venha a ser definida pelo Brasil. Considerando que a confirmação diagnóstica é, muitas vezes, feita no exterior e que a publicação dos relatos de casos é, em geral, feita em revistas internacionais especializadas, a maioria em inglês, o fluxo de informações termina sendo muito mais eficaz para fora do que internamente.

Não há como deixar de aproveitar as oportunas observações de Sgambatti de Andrade sobre a importância do aproveitamento da Internet para a vigilância de doenças emergentes, para registrar, mais uma vez, o quanto a questão da regulamentação do patenteamento da vida no Brasil tornou-se um tema político crucial. Sem adentrar pelos aspectos éticos dessas discussões, penso que sua introdução eventual - o que espero não venha a acontecer - irá restringir ainda mais o fluxo internacional de informação científica e tecnológica. Por outro lado, também poderá vir a comprometer a universalidade do acesso em saúde aos resultados da pesquisa científica e do desenvolvimento tecnológico, como, por exemplo, futuras vacinas para doenças emergentes, tendo em conta os impactos que terá sobre os preços de produtos finais, no complexo médico-industrial.

Considero que a circulação da informação científica e tecnológica, no Brasil, ainda é insuficiente, inadequada e desprotegida - ousaria afirmar que a comunidade científica brasileira, 
mas não apenas ela, ainda ignora a importância da informação que produz, no contexto técnico-econômico deste final de século. Apesar das limitações das bases de dados existentes, a capacitação nacional em certos campos, surpreende. É o caso das arboviroses.

Certas doenças são ignoradas até mesmo pela mídia que, corno chamam a atenção Serufo e Schatzmayr, especializou-se em veicular imagens sensacionalistas. Se a mídia peca por excessos, não há, entretanto, como deixar de registrar as contribuições importantes que alguns jornalistas vêm dando ao campo das doenças emergentes/re-emergentes. Há cerca de três anos, passei ao Schatztmayr cópia de um artigo fascinante que encontrei na The New Yorker, publicado antes do livro "Hot Zone" e do Ebola estourar novamente na África, em 1995. Recentemente, colaboramos - eu, e muitos outros pesquisadores brasileiros - para uma matéria no tema, preparada pela jornalista Terezinha Costa para a revista Globo Ciência e avalio que o resultado foi excelente.

Recomendo a leitura do livro "The Coming Plague. Newly Emerging Diseases in a World Out of Balance", da jornalista Laurie Garret (editado por Farrar, Straus e Girow/New York, 1994). Trata-se de um trabalho monumental. Tive oportunidade, em duas ocasiões diferentes, de manter contato profissional com a Laurie. A primeira vez, no outono americano de 1993, em um seminário promovido pelo Grupo New Diseases da Universidade de Harvard, e realizado nos Marine Biology Laboratories, na cidade de Woodshole, na Costa Leste dos Estados Unidos.

Não notei restrições da parte dos cientistas americanos pelo fato de tratar-se de uma jornalista. Ao contrário, tratavam-na com a mesma reverência acadêmica que conferiam aos demais cientistas presentes, e as opiniões eram unânimes quanto à seriedade do sério trabalho de pesquisa que estava sendo feito pela jornalista, em Harvard. Em junho de 1995, volteia encontrar a Laurie em Nova York, em outro seminário no tema. Seu livro tornara-se um best seller em poucos meses. Com certeza, a versão para o português será lançada em breve por aqui e repetirá o sucesso que vem tendo em outros países.
Destaquei essa questão por considerar muito importante a contribuição que os cientistas podem vir a da imprensa, no Brasil, no desenvolvimento de um jornalismo científico de qualidade e ético.

Maria Hortal referiu-se à resistência que microorganismôs desenvolvem por intercâmbio genético intra e interespécies, como nos casos do S. pneumoniae e dos enterecocos. Schatzmayr menciona fatos biológicos irreversíveis e mutações aleatórias na evolução biológica. Gadelha mencionou os desafios colocados pelos prions e virions - novas formas virais - para a detecção e vigilância de doenças emergentes. São observações que suscitam diferentes questões de ordem teórica e que discuto a seguir.

Antes, porém, é necessário destacar o problema dos conceitos de "novas" doenças e de doenças emergentes, para o qual chamaram a atenção Gadelha e Serufo.

Frequientemente, presume-se que o aparecimento de um "novo" microorganismo causador de doença é o resultado de uma mudança genética. Outras vezes, a emergência é claramente imputada às mudanças no ambiente e na ecologia humana. Com razão, Serufo, em seus side comments - que não destinou à publicação - pergunta: as doenças re-emergentes devem ser entendidas como "novas" doenças infecciosas? É possível separar conceitualmente emergência e re-emergência?

Bem, Gadelha ofereceu uma contribuição concreta, apresentando a categorização proposta por Mirk Grmek, a partir de cinco situações em que uma doença pode ser considerada emergente; também sugere o desenvolvimento, no terreno conceitual, das diferenças entre "novidade" e "emergência", referindo-se aos conceitos de "patocenose" e momentos de ruptura de equilíbrios patocenóticos na explicação da emergência (e não da novidade). Não conheço os trabalhos de Grmek, mas encontrei uma certa proximidade, na leitura da apresentação que deles faz Gadelha, com as discussões atuais sobre emergência de "novas" doenças, focalizando a importância relativa da evolução de agentes de novo em comparação à da transferência de agentes já existentes para novas populações de hospedeiros (o denominado microbial traffic). 
Realmente, as diferenças entre "novo", "emergente" e "re-emergente" são tratadas superficialmente na literatura médica e biomédica, ao contrário do que parece ocorrer na historiografia, segundo indicam os comentários de Gadelha. Para mim ficou, entretanto, a dúvida se os estudos feitos nas interfaces entre biologia, ecologia e história estão incorporando as discussões atuais sobre a problemática-histórica-do determinismo.

Embora não tenha ressaltado, no texto em debate, as limitações que encontro nas atuais classificações do novo, do emergente, do reemergente, na verdade, quando trato da previsibilidade referida à interpretação da causação, estou entrando na problemática do determinismo e da questão conceitual, ainda que sumariamente. Sem adotar nenhum conceito, porque considerei - e considero - prematuro, não pretendi, portanto, como entendeu Gadelha, regredir a algum reducionismo explanatório, do tipo tentar explicar toda a biologia pela ecologia ou pela economia ou em termos genéticos ou físico-químicos.

Em minhas atuais preocupações com as doenças emergentes, tenho em mente a seguinte pergunta: poderá a epidemiologia beneficiar-se, futuramente, da substituição de seus pressupostos mais tradicionais, dos mecanismos determinísticos, por um novo paradigma evolucionário?

Esta questão hoje se faz presente, em muitas áreas da ciência, a partir do momento em que a filosofia da complexidade encontrou suporte no campo da evolução biológica e passou a ser explorada enquanto um recurso alternativo às abordagens reducionistas. Sobretudo, o problema do deteterminismo é complexificado no campo das ciências físicas, nas idéias de caos determinista, caos organizador, estruturas desordenadas, caos quântico. Mas existe uma verdadeira explosão de trabalhos sobre o caos, em quase todos os domínios do conhecimento.

Penso que não se trata apenas de contrapor ao determinismo, a imprevisibilidade e a complexidade. Para dar conta de responder a essa indagação, ainda há muito que caminhar na direção, apenas indicada, introdutoriamente, no trabalho em debate.

Penso, acompanhando Prigogine e Stengers em "Entre o Tempo e a Eternidade", que é possível falar de uma gênese físico-química da informação, sem que isto signifique reduzir a biolo- gia e a história às leis físico-químicas, antes revelando a riqueza das relações entre processos, acontecimentos e circunstâncias que ganham um sentido longe do equilíbrio.

Advertem Prigogine e Stengers que as teorias da evolução darwinianas apresentam a evolução como simples produto de forças seletivas, atuando em mutações de ocorrência aleatória. Mas, indagam, são as mutações ocorrências aleatórias ou não são? Na ausência de qualquer informação concernente à natureza exata da variabilidade, entendem que a hipótese da total aleatoriedade é a mais plausível, tanto que o próprio Darwin a adotou. Muitas outras hipóteses são, entretanto, possíveis, desde a completa aleatoriedade, até o puro determinismo ecológico, no qual o ambiente é que determina totalmente qual mutação ocorrerá. A teoria darwiniana não é, portanto, preditiva e constitui apenas uma explanação plausível dos fenômenos observados no reino animal.

No seminário antes referido, de junho de 1995 - Emerging Infeccious Diseases: Meeting the Challenge, promovido pela The New York Academy of Medicine -, presenciei o Prêmio ,Nobel Joshua Lederberg, discorrendo a respeito do futuro das doenças infecciosas, mencionar, a propósito dos mecanismos de co-adaptação e troca de DNA que "... DNA é DNA e não reconhece espécies!” Com esta afirmação, Lederberg estava sugerindo que o processo evolucionário é muito mais complexo do que a explicação darwiniana sugere!

Muito têm contribuído para esta reviravolta as pesquisas sobre a Encefalopatia Espongiforme Bovina ou Prion Disease, incluída como doença emergente no relatório do Institute of Medicine, que cito no texto. Este exemplo é importante porque, historicamente, uma doença é, geralmente, reconhecida antes dos seus agentes específicos. Novas técnicas genéticas e conhecimentos moleculares estão invertendo esta situação, e os agentes causais de muitas doenças emergentes são identificados simultaneamente ou, até mesmo, antes das síndromes associadas às doenças. No caso da Doença de Prion, as discussões sobre as medidas a serem tomadas estão se pautando pela antecipação dos riscos epidemiológicos, "puxando", desse modo, o desenvolvimento científico e tecnológico correspondente. 
Em que momento a AIDS deixou de ser um problema hipotético e passou a ser uma questão concreta, de ordem operacional para os cientistas norte-americanos e europeus'? Certamente, não foi a partir do momento em que se contabilizaram as mortes e extraiu-se uma discussão estéril sobre o conceito de epidemia. Em 1995, em menos de duas décadas, essa trágica enfermidade tornou-se a primeira causa de morte entre indivíduos de 25 a 44 anos de idade, em certas partes do Primeiro Mundo, como na "abrasileirada" megacidade de Nova York.

De certa forma, as respostas às bem fundamentadas preocupações de Kloetzel sobre como fazer com que se aceitem novos conceitos e como conseguir que recursos sejam alocados para pesquisar hipotéticas endemias, já estão sendo dadas, no plano da ciência internacional, como comprovam a Encefalopatia Espongiforme Bovina e a AIDS. Penso que se trata, portanto, de levar na devida conta - nos planos acadêmico e da política de ciência e tecnologia em saúde - os riscos hipotéticos ou teóricos de futuras doenças emergentes.

Para Serufo, não há como discutir emergência e re-emergência de doenças sem se pronunciar sobre questões políticas - e, acrescento, éticas e de segurança - emergentes, nos plano nacional e internacional. Certas enfermidades, realmente, só são valorizadas quando passam a ser percebidas como motivos de risco universal. A recente epidemia do Ebola leva à seguinte indagação: quem se encarregará de desenvolver e de fabricar uma vacina específica, apesar da miséria do Zaire? Esta é uma questão que toca fundo na atual ética universal nos aspectos dasaúde e do ambiente, onde predomina o enfoque instrumental e mercadológico.

Não se trata, portanto, de tentar prever o imponderável, em detrimento do instrumentalismo, como entendeu Schatzmayr. O pensamento simplificador rejeita a incerteza. Mas o conhecimento científico deve confrontar a incerteza, o acaso, o indeterminável e o imprevisível, porque também fazem parte do mundo real. O pensamento biológico moderno trabalha com o acaso e toda inovação evolutiva comporta acontecimentos aleatórios. E é a incerteza e não a certeza que estimula a criatividade intelectual.

Rattner, em seus comentários, concorda que a tese que associa a emergência de novas pa- tologias à inovação e generalização de tecnologias permite várias análises e inferências. Seus comentários me fizeram pensar nos que estão em busca, na atualidade do pós-socialismo, dos caminhos que poderão conduzir a um novo humanismo. Os novos humanistas refletem sobre o futuro e lutam para superar a crise geral atual. São otimistas e acreditam na liberdade e no progresso social. São internacionalistas e aspiram uma a nação humana universal, porém múltipla: por suas etnias, seus idiomas, costumes, regiões, idéias, aspirações, crenças, ateísmo e religiosidade. Múltipla no trabalho e na criatividade.

Concluo deixando um fragmento da poesia de Robert Frost:

Two roads diverged in a wood and I took the one less traveled by and this has made all the difference 